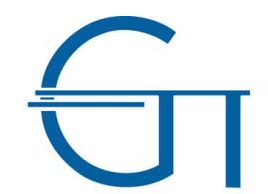

The Hellenic Observatory

The European Institute

\title{
Ten Years of EMU: convergence, divergence and new policy priorities
}

Nikos Christodoulakis

GreeSE Paper No 22

Hellenic Observatory Papers on Greece and Southeast Europe

January 2009 


\section{Table of Contents}

ABSTRACT _ iii

1. Introduction __ 1

2. Measuring convergence ___ 8

2.1. Business cycles ___ 9

2.2. National and regional income convergence ___ 13

2.3. Catching-up__ 16

3. Current Account deficits __ 20

3.1. The emergence of new asymmetries___ 20

3.2. CA Deficits and FDI flows ___ 23

4. Facing the asymmetries: in search of new policy priorities ___ 27

5. Conclusion _ 31

References __ 33

\section{Acknowledgements}

The paper was prepared as part of the National Bank of Greece Research Fellowship in the Hellenic Observatory, European Institute, LSE. The author is thankful to V. Monastiriotis for extensive comments and suggestions, and also to participants in seminars given in ELIAMEP, Athens, the University of Thessaly, and the Bank of Greece. The usual disclaimer applies. 


\title{
Ten Years of EMU: convergence, divergence and new policy priorities
}

\author{
Nikos Christodoulakis $\#$
}

\begin{abstract}
As the tenth anniversary of EMU is approaching, a debate is underway as to whether the single currency has promoted or hindered convergence among the countries of the Eurozone. On the one hand, there is wide agreement on the fact that asymmetric shocks have subsided after the creation of the single currency and that FDI has been substantially promoted both in and outside of EMU as a result of reduced exchange rate volatility, more integration and better institutional functioning.
\end{abstract}

But if one moves to examine the catching-up process between the less and more-affluent countries of the Eurozone, the evidence in support for convergence is fading away after the EMU was initiated in 1999. A process of divergence in per capita GDP is underway, in contrast with the substantial progress that has taken place during the nineties. Regional convergence is also found to wane, though the evidence is not as conclusive. Moreover, post-EMU divergence in per capita GDP appears to be far more pronounced than that of per capita GNI, due to the risk-sharing strategies implemented after the

\footnotetext{
\#Athens University of Economics and Business and London School of Economics, European Institute, Hellenic Observatory.

Correspondence: Athens University of Economics and Business, 76 Patission Street Athens 10434, Greece Email: nchris@ aueb.gr, N.Christodoulakis@1se.ac.uk.
} 
EMU to face asymmetric shocks and the resulted relocation of capital.

Another worrying development in the Eurozone is the emergence of unprecedented CA deficits in the Southern Eurozone countries, while the Northern Eurozone group enjoys substantial surpluses. Although both groups of countries have attracted increased FDI flows after EMU, there seems to be a sharp differentiation regarding size and composition. In the Southern countries, the housing sector has attracted relatively more investment than the production sector, while the reverse seems to be the case in the Northern group. Thus, investment in the Northern (Southern) Eurozone countries increased the traded (non-traded) output and caused an improvement (deterioration) in the trade balance. To face such imbalances, new policy priorities are required in the Eurozone that put more emphasis on convergence and competitiveness.

Keywords: Eurozone; economic integration; convergence; business cycles. 


\section{Ten Years of EMU: convergence, divergence and new policy priorities}

\section{Introduction}

The paper considers developments in a number of output indicators and the external balances in the Eurozone countries both before and after the Economic and Monetary Union (EMU) in order to assess how convergence on economic fluctuations and the level of income across member-states has been affected by the adoption of the single currency in 1999. Although multi-faceted and sometimes vague, the notion of 'economic convergence' has been deeply entrenched in European politics from the early period of the founding fathers up to the present, perhaps more than any other objective in the plethora that has been ambitiously accumulated by Brussels over the years. During the past half century, the drive for economic convergence has shaped several ideas and visions of the Union and has frequently become the test-bed of many policy initiatives. One of the most far-reaching among them, was the massive transfer of Structural Funds initiated in the mid-1980s towards the least-developed regions of the European Union. The program was conceived, and expanded, on the grounds of achieving greater 'cohesion' and assimilation in areas stretching from the Finnish province of Kainuu to the island of Crete and from the SubCarpathian region to Coimbra by the Atlantic. 
One of the most critical assumptions for the successful implementation of EMU was that economic fluctuations would converge, becoming less pronounced and more synchronised since a single monetary policy could be efficiently conducted only in the absence of conflicting views on the direction of correcting the cycle. The pre-EMU debate during the 1990s was also dominated by the so-called 'nominal convergence' of fiscal and monetary indicators that became a prerequisite for an economy to join EMU. Although public debates at that time were questioning the relative merits of 'nominal' versus 'real' convergence, it was widely viewed that participation in EMU would nevertheless speed-up both types of convergence in many ways. Dyson (2000), for example, argues that EMU was expected to be a powerful top-down instrument to catalyze convergence not only of markets, but also of policymaking institutions and welfare-state provision.

But above all, 'convergence' was meant to imply the gradual rise in real incomes and welfare in a non-inflationary environment (Kok, 2004). In a characteristic speech on the first anniversary of EMU, the president of the European Central Bank (ECB) remarked that the single currency will enhance regional growth and prosperity by helping the SMEs and promoting more trade opportunities (Duisenberg, 2001). For several countries it was precisely this prospect of accelerating real convergence that helped governments to win the support of public opinion for carrying out the fiscal and market reforms that were necessary to qualify for the EMU project. Thus, as noted by Begg (2003), after EMU was established and started to get more consolidated attention was 
inevitably focusing more on whether its benefits are shared equitably by its members.

Pledges to that end were never in short supply. Responding to the high expectations of the time, the 'Lisbon Strategy for Growth' that was launched in 2000 included a comprehensive set of targets to gauge the effectiveness of policy reforms in the member-states as a means to accelerate convergence. Quite naturally, top among them was the target of bridging the incomes gap between the most and the least affluent areas in the EU. Hence, the question of whether the single currency has actually promoted or hindered convergence in regional and national incomes is legitimately regarded as one of primary importance both for policy evaluation in EMU and a political prerequisite to increase support among the European citizens for further integration.

Another crucial aspect of pre-EMU considerations was the existence of prolonged and substantial trade and Current Account imbalances between the European economies. Deficit countries were frequently confronted with the dilemma of either having to devalue their currencies to improve the external deficits at the expense of domestic inflation and deteriorated terms of trade, or seeing their labour force migrating to the more developed regions of Europe. The Economic and Monetary Union project was in many ways inspired by the realization that by adopting a common monetary policy the European economies had a lot more to gain in welfare terms than being engaged in titfor-tat devaluations to redress imbalances in their Current Accounts. The gains 
from adopting the single currency were ranging from the elimination of exchange rate volatility and transaction costs to the facilitation of factor mobility within EU that was supposed to foster growth and enhance competitiveness across countries. Thus, major Current Account imbalances could be avoided and the pressure for beggar-my-neighbour policies would subsequently become extinct.

Although never formally considered as an explicit target in the Stability and Growth Pact, external imbalances were not expected to diverge sharply in the Euro Area, at least not to the extent it is being witnessed over the last few years, with Current Accounts ranging from a post-EMU average deficit for Greece of almost $7 \%$ of GDP to an average $7 \%$ surplus for Finland. Such phenomenal deviations in the Current Account (CA) constitute a new and mostly unforeseen type of asymmetry in the Eurozone that blends uneasily with the national and regional income divergence. When the deficit-prone countries are also lagging behind in terms of per capita income, the only policy choice they have is to embark on far-reaching structural reforms to raise competitiveness and enhance growth ${ }^{1}$.

However worrisome such developments might seem for the sustainability of the common currency, they did not attract extensive policy attention after the EMU was established. The assumption in the European policy-making bodies was perhaps that swollen CA deficits are no more than a transient phenomenon

\footnotetext{
${ }^{1}$ For if a government tries to contain the external deficit by traditional demand-cutting measures, this will inevitably exacerbate the income gap from the most-developed economies.
} 
as countries enjoy a post-EMU consumption spree due the fall of interest rates. For example, Blanchard and Giavvazzi (2002) disregarded any explosive possibility in the medium-run and discussing “... whether the current attitude of benign neglect vis-à-vis the CA in the Eurozone is appropriate, or whether countries such as Portugal or Greece should worry and take measures to reduce their deficits ... conclude, to a first order, that they should not", (Introduction, p. 3, my emphasis).

Only when CA deficits reached alarming levels over the last few years, a public debate on the potential threats to the economies of Southern Europe and their viability within the Eurozone started taking place. Blanchard (2006) turned away from his early benign-neglect suggestions and stressed that as "...CAD steadily increased...within the Euro, Portugal [and] Spain [have a] reason to worry...[as] deficits are too large,...[and] implications can be bad",(Introduction, p. 5). More to the point, Gros (2006) in a comparative study of Germany and Italy extends the risks of external imbalances to the potential abandonment of the monetary union by warning that if "... current trend could continue ... leading to an ever increasing loss of competitiveness... Italy's participation in EMU would be in doubt... as the country would need a massive devaluation"(p. 17).

According to the 'twin deficit' proposition, Current Account imbalances are demand-driven effects engineered by large fiscal deficits; for example see Gruber and Kamin (2008) who attribute the large US CA imbalances to the 
oversized government deficit. In other cases, CA deficits are explained by the intensive investment to enhance supply-side capacity especially in periods of transition, as for example in the emerging markets of Eastern Europe. Aristovnik (2006) finds that as potential domestic output exceeds the current level of production, most transition countries are justified in running relatively high Current Account deficits. However, evidence for the Eurozone countries is not supporting such views on the deterioration of the Current Account deficits. In a recent study for Italy, Spain, Portugal and Greece, Arghyrou and Chortareas (2008) suggest that 'other factors beyond income growth may explain the CA positions of these countries', (p. 755), and document that developments in the real exchange rate is a decisive one.

The present paper suggests that the divergence between external accounts may be at least partly attributed to the different patterns of inward and outward FDI across the countries of the Eurozone. Although both the Northern and the Southern group have attracted increased FDI flows after EMU, there seem to be noticeable differences in size and composition. In the Southern countries, the housing sector seems to have attracted more investment relative to that in the production sector, while the reverse appears to be the case in the Northern group. This has led to a shift in the composition of traded and non-traded capital stocks in the Eurozone economies and to the so-called "Rybsczynski effect", according to which an increase in a factor of production shifts the composition of output in favour of the sector which is relatively intensive in that factor. Thus, investment in the Northern (Southern) Eurozone countries 
tends to increase the traded (non-traded) output and, in the first place, causes an improvement (deterioration) in the trade balance. On the other hand, factor payments stemming from FDI endowments enter the Current Account and the net outcome is unclear. A country that receives FDI, mainly in the traded sector, raises productivity and the trade balance beyond the income outflow, so that its Current Account is improving. The Current Account is likely to deteriorate when FDI takes place mainly in the housing sector, so that international competitiveness is not improved and trade balance worsens.

The rest of the paper is organized as follows: section 2 examines the convergence and assimilation of business cycles of the various economies and then the catching-up process between the least and most developed Eurozone countries is assessed by employing four indicators of per capita income. By using the standard Hodrick-Prescott (1980) filter on per capita GDP, a higher convergence of the business cycles is found to have taken place across member-states after the EMU was established. On the other hand, using standard measures of dispersion and catching-up speed, it is found that postEMU developments in incomes are diverging, in contrast with a visibly stronger convergence process before its implementation.

In section 3, the Eurozone economies are classified into two groups according to whether they are in surplus or deficit in their trade balances and the Current Accounts after the creation of EMU. This results into one group consisting of the Northern economies with strong external surpluses, while the other includes 
the Southern economies of the Eurozone which show unprecedented deficits in the Current Account. The second part of this section examines how the different patterns of post-EMU foreign direct investment flows into the two groups has impacted upon the composition of output. In section 4, the paper addresses some limitations of the existing EU policy framework that make it inadequate to address the weakening process of convergence in the Eurozone. More extensive coordination and policy focusing is required at the EU level in order to reverse the current process of divergence, thus making the Eurozone a more successful and delivering European project. Conclusions are summarized in the final section.

\section{Measuring convergence}

In the literature of economic integration, convergence is a broadly defined concept, used to describe diverse issues ranging from income-dispersion indices to the assimilation of trade patterns and the affinity of social policy. Appropriate indicators of incomes convergence include the fluctuations of GDP around its trend and the variability of income in per capita terms measured as Gross Domestic Product, Gross National Income, at the national or regional level and in real or purchasing-power terms.

Convergence is assessed by looking at two measures of dispersion: the coefficient of variation and beta-convergence (Barro and Sala-i-Martin, 1995). The coefficient of variation measures the cross-country standard deviation of 
the time-series expressed as a percentage of the mean at each particular period. Beta-convergence measures the speed at which lagging-behind countries tend to 'catch-up' with the most advanced members of the group under examination. The first approach is employed to study the dispersion of business cycles and between per capita incomes in the Eurozone countries. The second is looked upon to assess the acceleration or slowing-down of the convergence process after EMU was started.

\subsection{Business cycles}

One of the most critical tests of EMU was expected to be the extent to which idiosyncratic shocks impinging upon particular economies lead to asymmetric economic fluctuations of such intensity that could jeopardize the viability of the common monetary policy and the issue had attracted a lot of attention and debates before EMU was formally established; see among many others Bean (1992), Cohen and Wyplosz (1989), Weber (1990), etc. The critical question was whether the economies involved in the integration process would have similar or differing responses to shocks with regards to timing, intensity and persistence. In the case of asymmetric responses to shocks, EMU would be under strain as it should have to respond to different patterns of the business cycle across each member-state and this sooner or later could lead to its disintegration; see Bayumi and Eichengreen (1992).

A different line of approach was stemming from the so-called 'endogeneity' argument in the theory of currency unions - see for example Tenreyo and Barro 
(2003), who argue that currency unions are likely to decrease the co-movement of output. Using trade data of twenty industrialized countries over thirty years, Frankel and Rose (1996) establish that economies with closer trade links tend to have more tightly correlated business cycles. The conclusion logically following from the endogeneity argument is that ex-ante differences in the business cycles should not hinder the implementation of the single currency. Christodoulakis et al., (1996) found that most of the pre-EMU dispersion was due to idiosyncratic aspects of national policies that naturally would tend to diminish afterwards. In a similar vein, a study commissioned by the European Parliament (1998) pointedly argued that ' ... many of the asymmetries might be removed by the coordination within EMU of economic policies, the alignment of legislation (e.g. in the area of financial services or labour law) and by the fact of monetary union itself' (summary/conclusions, no. 3).

To find out whether the implementation of EMU has affected the pattern of business cycles in the individual economies, we examine the fluctuations of their outputs around a trend. Per capita output of any type in constant prices ( $y$ ) is decomposed into a trend $(z)$ and cycle $(u)$ for each country $\mathrm{j}(\mathrm{j}=1, \ldots, \mathrm{n})$ at period $t$ according to:

$$
y_{j}(t)=z_{j}(t)+u_{j}(t)
$$


Employing the Hodrick-Prescott method ${ }^{2}$, we obtain the cycles of per capita GDP in constant prices for the first 12 Eurozone countries. As it is clearly demonstrated in Fig.1a, GDP cycles have become more symmetric and less intensive after EMU.

Second, we evaluate a measure of the dispersion of fluctuations across the members of the Eurozone, defined as the percentage ratio of the standard deviation of cycles over the trend mean, namely:

$$
V B C(t)=100 \cdot S D\left[u_{j}(t)\right] /\left[\frac{1}{n} \sum_{j=1}^{n} z_{j}(t)\right]
$$

Cross-country variability of business cycles (VBC) is depicted in Fig.1b and shows a substantial reduction from around $2 \%$ of the trend mean in early 1990 s to around $1 \%$ in the latest years. The above results imply that the implementation of EMU not only was not hindered from prior business cycles asymmetries, but it coincided with further dampening and more synchronization among countries. It is less clear, however, whether this moderation was a direct impact of EMU or an effect coincidental with the more globalised international environment prevailing after 2000; for a discussion see Schelkle (2007). Giannone and Reichlin (2006) evaluate a wide range of

\footnotetext{
${ }^{2}$ This procedure is based on the definition of the business cycle component of a variable as the deviation from its smoothed trend; see Hodrick and Prescott (1980). In commonly-used econometric software the representation of this smoothed trend is a time-sequence that minimizes a second-order criterion of smoothness.
} 
business cycles indices ${ }^{3}$ confirming that gaps between member-states are smaller after EMU and cycles mostly synchronized. However, they notice that a similar moderation is observed in other non-EMU economies of the OECD.

Other studies seem to be more conclusive on the EMU-induced dampening and synchronization of business cycles, due to the increase of intra-trade activity and a closer coordination of fiscal policies. Altavilla (2004) presents evidence showing that, since the establishment of the Maastricht Treaty, EMU members' business cycles have become more assimilated between themselves than with the United States. In a similar vein, Schiavo (2007) attributes most of the dampening to the 'endogeneity' effect of EMU, i.e. the fact that member-states tend to move more closely together once they belong to the same monetary union.

As a matter of fact, several idiosyncratic shocks that fell upon the European economies in the 1990s and caused severe asymmetries in their growth patterns did not originate from the lack of a common monetary policy. For example, the banking distress in Finland and the demand surge in Germany in the aftermath of the unification produced strong idiosyncratic fluctuations of GDP. As none of such episodes was repeated, it is not surprising that cyclical movements subsided considerably. But other types of pre-EMU shocks, including uncoordinated demand management and the failure of ERM in several

\footnotetext{
${ }^{3}$ The covariance of GDP per capita growth rates shown in Fig.4 for the period 19992007 are close in magnitude with those reported in their calculations over the period 1993-2003 (Table 3, col.6). Comparisons over the period in early 1990's are not possible as they omit the years 1990-92 to avoid the excessive shocks associated with the German unification.
} 
countries during 1992-93, could be attributed - at least partly - to the absence of a single monetary policy. The very existence of EMU precludes several of such shocks by ruling out devaluations and making the common monetary policy to have symmetric demand effects across member-states.

\subsection{National and regional income convergence}

To assess how convergence of incomes was involved before and after EMU, two well-established methods are employed: First, the so-called " $\sigma$ convergence" is defined similarly with (2) as the variability of per capita income (VPI) in constant prices:

$$
V P I(t)=100 \cdot S D\left[y_{j}(t)\right] /\left[\frac{1}{n} \sum_{j=1}^{n} y_{j}(t)\right]
$$

where $y_{j}(t)$ is a measure of income in country $j(j=1, \ldots, n)$ at time $t$. Four measures of income are taken in turn namely GDP, regional GDP, GDP in Purchasing Power Standards (PPS), and Gross National Income (GNI), all expressed in per capita terms and constant prices for the 11 European countries, excluding Luxembourg ${ }^{4}$. Data are described in the Appendix. Computing dispersions as in (3), we obtain the results graphically depicted in Fig.2a-c. The following remarks can be made:

\footnotetext{
${ }^{4}$ As commonly done in similar measurements, Luxembourg is not included in the sample - otherwise its pervasive hikes of income due to capital movements would exert a disproportionate influence on the Euro-area average.
} 
(i) Dispersion in per capita GDP in PPS terms reached the lowest level since 1996 in 2003, but then started increasing again, and in 2007 it surpassed the level it had back in 1997.

(ii) The most noticeable reduction in the dispersion among member-states before EMU regards regional incomes, which fell by more than four percentage points over the period 1995-97. The convergence process is not found to continue any more after 1999, confirming earlier studies on the post-EMU weakening of regional convergence; see, for example, Martin (2001) and Gardiner et al. (2004).

(iii) Cross-country dispersion indices for per capita GDP and GNI evolve upwards after 1992, in contrast with their downward pattern up to that year. The variability index rises to around $31 \%$ of the Eurozone average, effectively returning to the level it had in the mid-1980s.

All these findings suggest that the process of incomes convergence between Eurozone members has been at best halted or substantially reversed, depending on the index under consideration. Moreover, GNI seems to have a smoother pattern of dispersion than that of GDP for most of the period after EMU, in contrast to following virtually the same course before EMU. A reason behind the slower deviation of GNI relative to GDP, can be the so-called strategy of risk-sharing. According to this, factor endowment and economic activity is spread across countries as a way to reduce the impact of idiosyncratic shocks that impinge on a particular economy of the Union. Thus, while GDP varies 
when affected by shocks, risk-sharing reduces the transmission of output fluctuations onto the national income and consumption.

In the early 1990s the two indices of GDP and GNI dispersion were almost identical, which implies that income risk-sharing was hardly taking place at that time. But subsequently, and all the more after EMU, GNI is evolved differently than GDP, suggesting that a higher degree of risk-sharing strategies was employed in the Eurozone to alleviate the impact of idiosyncratic shocks and smooth consumption over time. Kalemli-Ozcan et al. (2004) estimate that the degree of risk-sharing in the European Union has increased substantially since the mid 1990s due to increased cross-ownership of assets across countries and is expected to grow further in EMU as transaction costs were decreased and several institutional impediments were lifted. In contrast, cross-country GDP developments seem to be sharply diverging ${ }^{5}$.

Another fact is that, although not improving any further, the dispersion index in regional incomes does not deteriorate at the same degree as happens with the other indicators. This can be attributed to the continuation of the growthfostering interventions in the least-developed areas financed by the Structural Funds the positive impact of which on regional convergence is extensively researched; see e.g. Cappelen et al. (2003) and Christodoulakis and Kalyvitis (2002).

\footnotetext{
${ }^{5}$ This measure concerns the level of each country's GDP and should not be confused with the reduction of the fluctuations discussed in Section 2.1 which is a measure of the cycle.
} 
The Third Community Support Framework (CSF) over the period 2000-06 was for some countries lower than the funds allocated to Eurozone regions through the Second CSF (1994-1999), as several regions achieved substantially high growth rates during the previous years that made them to be no longer eligible for cohesion funding. However, it seems ${ }^{6}$ that national governments used national resources to compensate for the reduction, so that total public investment over the period $1999-2007$ stayed in average at $2.71 \%$ of GDP among the eleven Eurozone countries, only slightly below the average public investment of $2.74 \%$ of GDP over the period 1996-98.

\subsection{Catching-up}

Another widely used concept in convergence measurements is the speed at which lagging-behind members of a group are 'catching-up' with the most advanced. Reviewing this process, (European Economy, 2008, Ch. 8, p. 106) finds that convergence has indeed weakened for some countries, such as Spain and Italy, although it claims that catching-up still applies for EU members as a whole. But it fails to note that after EMU convergence dynamics appear to be meaningful only when the newly accessed and faster-growing emerging economies of Eastern Europe are included in the test. This can hardly be taken as an indication of convergence that is attributable to the adoption of the single currency, since most of these countries are not yet participating in the Eurozone, while Slovenia, Cyprus and Malta account for only a small share of total population.

\footnotetext{
${ }^{6}$ Eurostat data; see Appendix.
} 
It seems more meaningful that the growth rates of per capita incomes are juxtaposed vis-à-vis the income levels of the Eurozone countries solely and for the two periods separately. Using the first year of each period as the base, simple correlations are obtained over two equal periods before (1990-98) and after EMU (1999-2007). Results in Figure 3 show a negative correlation coefficient $(\rho=-0.11)$ indicating that catching-up dynamics were present before EMU, albeit not particularly strong. However, even this weak correlation vanishes after EMU and is reversed in sign $(\rho=+0.045)$.

Due to the small size of the available sample, the above results may be highly sensitive to the choice of the first year. For this reason we also examine two other types of catching-up equations that can be estimated by using a larger number of observations. The first is a time-moving version of the familiar betaconvergence equation:

$$
\left[\frac{y_{j}(t)}{y_{j}(t-s)}-1\right]=c+d_{j}-\beta \cdot \log \frac{y_{j}(t-s)}{\overline{y_{j}}(t-s)}+\varepsilon_{j}(t)
$$

The 1.h.s. is the growth rate of per capita GDP ${ }^{y_{j}(t)}$ in country-j $(j=1, \ldots, n)$ over (s) periods, while the logarithmic term in the r.h.s. denotes the gap of that country relative to the mean of the group $\left({ }^{\bar{y}}\right) s$-periods back. If $\beta$ takes a high value, an initial gap in per capita income is bridged over time by achieving higher growth rate, but not quickly enough if $\beta$ is low. Thus, $\beta$ represents the 
speed of convergence, while $c$ is a constant, ${ }^{d_{j}}$ is a country-specific dummy and ${ }^{\varepsilon_{j}}$ is the error term.

Another formulation to measure convergence is to consider how the period-byperiod per capita GDP growth rate depends on a smoothed average of lagged discrepancies in the level of GDP of each country relative to the group mean:

$$
\left[\frac{y_{j}(t)}{y_{j}(t-1)}-1\right]=c+d_{j}-\beta \cdot \log \sum_{k=1}^{s} \frac{y_{j}(t-k)}{\overline{y_{j}}(t-k)}+\varepsilon_{j}(t)
$$

Both the above formulations are not specific to the choice of the reference year, but still depend on the lag $(s)$ over which growth rates and level gaps are measured. Choosing a high or a low value for $(s)$ corresponds to measuring convergence over the longer or the short run respectively. Indicatively, we choose here a lag of $s=4$, that represents a medium term consideration of convergence, as this is the typical duration of a government in most countries of the European Union and also happens that several convergence reports are published at a similar frequency to assess progress relative to its predecessors. ${ }^{7}$

The pooled group includes the eleven initial Eurozone countries (excluding Luxembourg) and estimation takes place over the two equal-size periods 199098 and 1999-2007, before and after the EMU respectively. Estimation of equation (4a) is using pooled least squares with cross-country fixed effects and

\footnotetext{
${ }^{7}$ Estimates with other lags produce similar comparisons between pre-EMU and postEMU speeds of convergence and are available by the author.
} 
an autoregressive structure $\operatorname{AR}(1)$ given by $\varepsilon_{j}(t)=\rho \varepsilon_{j}(t-1)+\omega_{j}(t)$, where $\omega_{j}(t)$ is an i.i.d. process . Estimation of equation (4b) employs EGLS of similar structure but now with cross-weights to improve the autocorrelation statistics. Unit-root tests are performed for the growth rates and the level gaps of per capita GDP and the hypotheses are rejected at the 5\% level as shown in Appendix B. Results are summarised in Table 1.

Table 1 Pool estimates of the catching-up process before and after EMU.

\begin{tabular}{|c|c|c|c|c|}
\hline & Pre-EMU (4a) & Post-EMU (4a) & Pre-EMU (4b) & Post-EMU (4b) \\
\hline constant & $0.04(3.069)$ & $0.029(0.95)$ & $0.357(2.55)$ & $0.25(2.37)$ \\
\hline beta & $1.22(4.93)$ & $0.68(3.20)$ & $0.25(2.40)$ & $0.15(2.17)$ \\
\hline AR(1) & $0.755(12.15)$ & $0.88(17.73)$ & $0.439(4.54)$ & $0.48(5.59)$ \\
\hline R2-adj & 0.76 & 0.90 & 0.39 & 0.56 \\
\hline DW & 1.08 & 1.06 & 1.92 & 2.18 \\
\hline
\end{tabular}

Note: t-statistics are shown in parentheses.

Results for both types of estimated equations reveal a significant weakening in the speed of convergence between the pre- and the post-EMU periods as the beta coefficient falls from 1.22 and 0.25 to 0.68 and 0.15 for the two cases respectively. The weakening in the catching-up dynamics may be explained by a variety of factors, including asymmetric developments in productivity and inadequate growth in the less developed economies. These can be attributed, at least partly, to the post-EMU reform fatigue as several governments found it politically expedient to continue a process that was frequently seen by public opinion (and conveniently accepted by short-term governments) as only a 
transitory obligation that expires with the accession to the Monetary Union. Duval and Emelskov (2006) argue that the up-front costs of structural reforms may be larger under a common currency and a more restricted use of fiscal policy. The slowdown of market reforms was combined with a depressed world demand and resulted in low growth and recession in several EMU countries, thus limiting the convergence process.

\section{Current Account deficits}

\subsection{The emergence of new asymmetries}

One of the most worrying, and least foreseen, developments in the Eurozone is the unprecedented widening of deviations in both the trade balances and the Current Accounts of the member-states. Table 2 shows the average balances for a period of nine years before and nine years after EMU. Two groups of the Eurozone counties are considered according to whether their trade balances have been in average improved or deteriorated after EMU. The group characterised as "North" includes six countries (but again not Luxembourg) and shows an average improvement of 3.23 percentage units of GDP in the Trade Balance, as opposed to an average deterioration of 3.78 units of GDP in the group of the five countries symmetrically termed as the "South". 
With the exemption of Ireland ${ }^{8}$, Current Accounts of the Northern group are in surplus after EMU and most of them (except Ireland and Belgium) improve further by an average of 1.52 percentage GDP units, while in the South they all deteriorate by 3.39 units. Three of the Southern Eurozone countries experienced CA deficits ranging between $5 \%$ and $9 \%$ of GDP in average during the last five years, almost three times the average range they had in the early nineties. On the other hand, the Northern countries of the Eurozone were reaching CA surpluses as high as 9\% of GDP, despite the hard Euro policy followed by the ECB.

Table 2. Trade balances (TB) and Current Accounts (CA) in the Eurozone as \% of GDP.

\begin{tabular}{|c|c|c|c|c|c|c|}
\hline Countries & $\begin{array}{c}\mathbf{1 9 9 0 - 9 8} \\
\text { TB }\end{array}$ & $\begin{array}{c}\mathbf{1 9 9 9 - 0 7} \\
\text { TB }\end{array}$ & $\begin{array}{c}\text { Change } \\
\text { in TB }\end{array}$ & $\begin{array}{c}\mathbf{1 9 9 0 - 9 8} \\
\text { CA }\end{array}$ & $\begin{array}{c}\mathbf{1 9 9 9 - 0 7} \\
\text { CA }\end{array}$ & $\begin{array}{c}\text { Change } \\
\text { in CA }\end{array}$ \\
\hline AT & 0.16 & 3.93 & 3.78 & -1.38 & 0.36 & 1.73 \\
BE & 3.48 & 3.79 & 0.31 & 4.32 & 3.84 & -0.48 \\
FI & 4.57 & 7.41 & 2.84 & 0.47 & 7.06 & 6.59 \\
GE & 0.44 & 3.81 & 3.37 & -0.54 & 2.24 & 2.78 \\
NL & 4.90 & 6.58 & 1.68 & 4.13 & 5.37 & 1.23 \\
IE & 12.15 & 13.93 & 1.78 & 1.78 & -1.61 & -3.39 \\
NORTH & $\mathbf{3 . 3 5}$ & $\mathbf{6 . 5 8}$ & $\mathbf{3 . 2 3}$ & $\mathbf{1 . 3 5}$ & $\mathbf{2 . 8 8}$ & $\mathbf{1 . 5 2}$ \\
IT & 2.44 & 0.60 & -1.84 & 0.57 & -1.01 & -1.58 \\
FR & 0.84 & 0.30 & -0.54 & 0.80 & 0.56 & -0.24 \\
PT & -7.55 & -8.63 & -1.08 & -2.19 & -8.76 & -6.57 \\
SP & -1.04 & -3.79 & -2.74 & -1.64 & -5.41 & -3.77 \\
EL & -6.95 & -11.89 & -4.94 & -2.39 & -6.71 & -4.32 \\
SOUTH & $\mathbf{- 0 . 9 1}$ & $\mathbf{- 4 . 6 8}$ & $\mathbf{- 3 . 7 8}$ & $\mathbf{- 0 . 8 8}$ & $\mathbf{- 4 . 2 7}$ & $\mathbf{- 3 . 3 9}$ \\
\hline
\end{tabular}

Note: Unweighted period averages. Source: IMF World Economic Outlook 2008, and Eurostat.

This represents a wholly new type of asymmetry in the Eurozone. Despite the fact that most of Southern European economies were historically prone to deficits, none of them saw its CA to deteriorate so fast and extensively in the

${ }^{8}$ After 2003, Ireland experiences CA deficits, due to rising Factor Payments abroad. However, the country continues to enjoy high surpluses in the Trade Balance and this justifies that it is included in the Northern group. 
past. For example, until 1999 Spain's CA deficits as percent of GDP were only $1.1 \%$ worse than Germany's, but in 2007 the gap surpassed 15 percentage units as Spain was having a deficit of $9.8 \%$ while Germany had achieved a surplus of $5.4 \%$ of GDP.

Although there is no established benchmark at which point a CA deficit may cause an economy-wide crisis, it is useful to recall that the Balance of Payments crises in Latin America over the last three decades took place with external deficits ranging between 6 and $8 \%$ of the respective countries' GDP, a level far below the recent ones seen in the Southern Eurozone countries.

To assess the implications that a large external deficit may have on the economy, Shelburne (2008) calculates the ratio of CA deficit to total capital formation and uses it as an indicator of risk associated with the easiness of the country's financing from abroad. These ratios are depicted in Fig.4b for the Southern Eurozone countries and show a rise in the post-EMU period, especially over the last four years. For Greece, Portugal and Spain, they have risen to levels of $35-45 \%$ making the financing of investment to depend crucially on the availability of international credit. The situation has been further aggravated by the global banking crisis of 2008 as the tightening of external deficit financing in combination with domestic budget imbalances led 
to unprecedented rises of sovereign borrowing costs in Eurozone countries ${ }^{9}$ never seen before in the EMU era.

\subsection{CA Deficits and FDI flows}

The 'twin-deficit' proposal can be examined ${ }^{10}$ by looking first at simple correlations between CA and government deficits in the Southern group. As Figure 5 demonstrates, the two deficits were weakly positively correlated $(\rho=0.1917)$ in the period before 1999, but this does not survives EMU as Fig.

5 b shows ${ }^{11}$. During that period, government balances became more streamlined towards the 3\% threshold imposed by the Stability and Growth Pact, but at the same time CA deficits were becoming even wider.

Perhaps a more promising framework to explain the vastly diverging developments in the external balances, is to examine whether the imbalances are 'supply-driven' and what factors might have led to different patterns of productivity and trade in the Eurozone countries. One suitable supply-side framework is the two-sector model of a small open-economy as described by Turnovsky (1996). The model assumes that two types of capital are accumulated in the economy, one which is traded internationally and the other that is non-traded. In the present context, inward FDI is of the former type,

\footnotetext{
${ }^{9}$ The highest spikes in spreads between the rates of ten-year bonds and the German bund were seen for Greece and Italy which are characterised by both CA and budgetary deficits. However, spreads went also up for Spain due to the high external deficit in spite of a low debt-to-income ratio and a budget in surplus..

${ }^{10}$ More properly, the link between the two deficits should be examined by looking for the existence of Granger-causality between the two deficits, but the short time-span after EMU makes the results of little value.

${ }^{11}$ If anything, Fig. $5 \mathrm{~b}$ suggests that there might be two subsets in the data showing a negative correlation between CA and government balances.
} 
while the second can be taken to express the capital stock invested in the housing sector. There are two sectors in the economy, one producing internationally traded goods while the other produces goods traded only domestically. Both types of capital are employed in both sectors of the economy, in a way similar to that developed by Wincoop (1990). However, factor intensities are different across the two sectors and the economy can be relatively capital-intensive either in the traded or in the non-traded sector, depending where traded-capital is employed more intensively.

The difference in the capital intensity gives rise to the so-called "Rybsczynski effect", according to which an increase in a factor of production shifts the composition of output in favour of the sector which is relatively intensive in that factor; see Rybsczynski (1955). Inward (outward) foreign investment can be treated as a rise (reduction) in the stock of traded capital that enters both sectors of production. The following implications for the two possible cases of relative intensity in traded capital can be derived from the Rybsczynski effect:

Case I: If the economy is relatively capital-intensive in the production of traded output, FDI will be directed in greater proportions to the traded sector. In this case, traded output expands relatively more than the output of the nontraded sector and, assuming that global demand for exports does not change given the small size of the economy, this improves the trade balance.

Case II: If the economy is relatively capital-intensive in the non-traded sector, then most of the internationally traded FDI will be attracted by the 
housing sector and production will shift towards the non-traded goods. As a result, the trade balance deteriorates.

Distinguishing between investment in the housing sector and investment in productive activities, a different pattern of inward investment and output composition emerges for the two groups: when FDI flows in an economy that is relatively capital-intensive in the productive sector, it is channelled mainly in that sector and leads to higher traded output. Normally, this accumulation also leads to substantial productivity improvements and, thus, stronger competitiveness in international markets. In contrast, if the economy is capitalintensive in the housing sector, FDI is going mainly to the non-traded sector, thus reducing traded output and boosting aggregate demand. As a result, prices rise, the real exchange rate appreciates and international competitiveness falls. Therefore the differentiation in the structure and composition of the economy has profound consequences on the supply side and can be used to explain at least part of the divergence in the trade Current Account balances in the Eurozone.

To examine the above implications of the Rybsczynski effect, correlations between Trade balances and inward FDI stocks are evaluated for the two Eurozone groups. As shown in Fig.6a, correlations are found to be positive for all the Northern Eurozone countries, while those shown in Fig. $6 \mathrm{~b}$ for the Southern countries are all negative. This can be taken as an indication that FDI flowing into the Northern group has been directed relatively more to the 
production sector, while FDI to the South has been mainly channeled toward the non-traded sector.

Another indication that FDI flows to the Southern Eurozone countries were mainly directed to the real-estate could come from the pattern of housing prices. Using house rental prices, Fig. 7 shows that house price increases in the Southern group were higher than those in the North. In the Northern group, Ireland experienced a housing bubble of a size comparable with those in the South, but nevertheless it managed to attract substantial productive investment leading to trade surpluses even higher than before EMU (see Table 2).

Apart from the composition of the FDI flows, there seems to be also a substantial difference in the volumes of investments attracted by the two Eurozone groups. In the event of the EMU, there has been a massive FDI net flow (i.e. inflows net of outflows) to the Northern countries of the Eurozone and an opposite net outflow from the Southern countries. Figure 8 demonstrates that both Eurozone groups were having a more or less similar net flow of FDI before EMU, but this changed dramatically when EMU was put in place. After 1999 Northern countries have been able to accumulate a stock of foreign capital that on a net basis went in average up to $10 \%$ of their GDP. In contrast, FDI inflows in the Southern countries have been surpassed by outward investment and this has led to lower capital stock on a net basis. Fillipaios and Papanastassiou (2008) provide extensive evidence of the fact that Northern countries have shown a greater adaptability to the new conditions created by 
EMU in attracting substantially more FDI flows from the US. The unequal distribution of FDI flows between the Northern and the Southern group is in agreement with the fact that Net Factor Payments from Abroad (NFIA) to the North are negative, leading to CAs that are lower than Trade balances as shown in Fig.4a. In the South, the substantial outflow of FDI has resulted to positive

NFIA in average, hence Current Account deficits are lower than the corresponding trade deficits.

\section{Facing the asymmetries: in search of new policy priorities}

When EMU was implemented in 1999, there were high expectations that the smooth functioning of the single currency would catalyze major improvements across the social and economic spectrum, making additional policy targeting to seem superfluous. This benign neglect constituted a departure from earlier policy patterns adopted by the European Union in which intermediate targets were typically set within specific time-frames and adequate financial resources were allocated to accomplish them. For instance, the Community Support Framework was a time-framed and outcome-specific tool aiming at reducing regional discrepancies where applied. Similar initiatives have been undertaken regarding a more efficient mobilization of knowledge capital or in order to coordinate enterprise networks. The same clear-objective pattern was adopted in preparing for the EMU, when the Stability and Growth Pact was conceived as a rule-abiding fiscal framework necessary to redress the lax state of public finances in several countries. 
Contrary to the comforting implications of the 'endogeneity' argument in a Monetary Union, the smooth introduction of the single currency and the successful dampening of inflation during the first ten years of EMU did not prove sufficient to symmetrically raise productivity across countries and speedup real convergence. In a monetary union as envisaged by Mundell (1961), factor mobility should have worked to equalize the marginal rates of returns over all countries. But in EMU-reality, mobility has thus far worked mainly for capital relocation and this seems to have aggravated the asymmetries in productivity in the tradable sectors and caused vast asymmetries in the external balances of the Eurozone countries.

It is true that one year after the formal start of EMU, an ambitious policy supplement was launched to encourage the European economies to raise competitiveness and achieve real-economy improvements. The Lisbon Strategy included several social and economic objectives claimed to be the fast way for driving the Union to meet the challenges in the new era of globalization. Incomes convergence was explicitly on the top of new priorities, but with no binding objectives or time-frame attached to it. Although there was no direct reference to $\mathrm{CA}$ targets, the Strategy was also advocating the rise in productivity that would cure the imbalances. But despite the initial thrust given to it by governments and its endorsement by several public institutions, it did not prove sufficient in speeding-up growth and convergence in the EU in general and the Eurozone in particular. A number of reasons why the Lisbon Strategy did not deliver on its targets might be the following: 
(a) It included too many targets and this frequently diluted the policy focusing and resulted to inadequate financing. In its five-year assessment report, the High Level Group headed by Kok (2004) admits that “... the progress of the Lisbon strategy has suffered from incoherence and inconsistency, both between participants and between policies", (p 39). It went on to suggest that "a better reflection of the priorities of the European Union in its budget would further enhance coherence at the European level".

(b) It set the same framework and objectives for all EU countries, irrespective of the fact that some of them were already in the Monetary Union, while others could still make use of a more independent monetary policy to face some idiosyncratic shocks that were threatening their productivity.

(c) The lack of prioritization in its objectives led to substantial revisions of its 'main message' to serve better the needs of the time. When it was launched in 2000, it was viewed as the vehicle to make Europe the most competitive knowledge society' in the world by year 2010. The emphasis was on promoting education and raising scientific and innovation potential in Europe to enable it competing with US and other, emerging economies. A few years later, a midterm look at the Lisbon strategy revealed that the outcomes were somewhat disappointing particularly with regard to employment. Responding to the bleak findings, the Strategy was re-launched as an agenda for 'Growth and Jobs' with the main focus on increasing labour market participation (EC, 2005). Barely two years later, the EU Presidency attempted yet another refocusing, this time 
on 'the four priorities' of (i) energy sufficiency, (ii) unleashing the potential of small and medium-size enterprises, (iii) increasing employment 'flexicurity' and (iv) improving the education standards (Barroso, 2007). Although each new set of priorities was in no way contradicting its predecessors, it was nevertheless causing confusion that diminished the overall credibility of the Strategy as a results-oriented process.

(d) Unlike the Stability and Growth Pact whose enforcement in each particular country is extensively assessed and debated in the EU policy groups, the Lisbon Strategy is examined once a year and receives little public attention in each country. Rather than following specific and universal rules, its implementation is encouraged by example and autonomous national initiatives, thus lacking a direct market response to its progress or the lack of it.

Given these features of the Lisbon Strategy, it is clear that the weakening of the incomes convergence process and the vast disparities shown in the Current Account balances can be addressed only if economic policy is refocused on such specific issues and further policy coordination, time frames and oversight are introduced in the Eurozone concerning the containment of external imbalances. The emergency situation caused by the international credit crunch in the autumn of 2008 can only make this policy shift more urgent and, hopefully, more far-reaching. 


\section{Conclusion}

The paper examined a number of output and income indicators in order to assess the degree of convergence across the economies of the Eurozone after the introduction of the Euro in 1999. Business cycles were found to be a lot less intensive and more synchronous than before EMU, thus suggesting that a higher degree of moderation and homogeneity in economic fluctuations has prevailed after the single currency was established. This has enabled the conduct of the single monetary policy as participating countries experience more or less common economic peaks and recessions and, therefore, seek a similar pattern of interest rate changes over the cycle.

The second finding concerned the dispersion in per capita output, which is found to systematically increase after EMU. By employing various measures of GDP, such as per capita in constant prices, regional or in Purchasing Power Standard, it is found that after a period of convergence in the late 1980s and early 1990s, dispersion in GDP per capita has risen sharply. This, in consequence, has brought the catching-up process between the less and more developed countries of the Eurozone to a halt, reversing the pre-EMU dynamics of convergence. Given that the 'real convergence' was envisaged as the natural continuation of the 'nominal convergence' phase that preceded the accession to EMU, its reversal may be seen by public opinion and policy makers as a limitation of the single currency and turn into an obstacle for further integration and reforms. 
But the most crucial asymmetry in the Eurozone has been the emergence of huge disparities in the Current Accounts and the Trade Balances, with the Northern members of the group reaping large surpluses while the Southern ones suffering huge external deficits. Despite the fact that at a Eurozone level most of these asymmetries are mutually dissipated and lead to an aggregate balance, deficit countries are burdened in terms of productivity and job losses. In periods of global financial strain, external deficits may also increase the cost of borrowing as became evident during the 2008 crisis.

CA deficits do not seem to be caused by fiscal excesses, but rather they are associated with supply-side effects stemming from differences in the composition of FDI flows to Eurozone countries. Countries with a relative capital intensity in exporting industries have attracted more foreign investment in the traded sector and, as a result, saw their external balances to flourish. On the other hand, countries with a relative capital intensity in the production of non-tradable goods and, more particularly, in the housing sector attracted FDI mainly in the real-estate market and suffered housing-bubbles, excessive consumption and external deficits. The existing policy framework in the Eurozone is not adequate to address such disparities and new priorities should be adopted including improvements in productivity and the restoration of external balances. To this effect, the so-called 'Lisbon Strategy for Growth' should be prioritized on achieving more convergence and competitiveness for the Eurozone members. 


\section{References}

Altavilla C., 2004, "Do EMU Members Share the Same Business Cycle?", Journal of Common Market Studies, Vol. 42, 5, pp 869-896.

Arghyrou M. and Chortareas G., 2008, "Current Account Imbalances and real Exchange Rates in the Euro Area", Review of International Economics, Vol. 9, 5, pp 747-764.

Aristovnik A., 2006, "The Determinants and Excessiveness of Current Account Deficits in Eastern Europe and the Former Soviet Union", William Davidson Institute, Working Paper No. 827.

Barro R. and Sala-i-Martin X., 1995, 'Economic Growth', McGraw Hill.

Barroso J., 2007, "Seeing the wood for the trees: The purpose of the Lisbon Strategy", Speech No. 07/67.

Bayoumi T. and Eichengreen B., 1992, "Shocking aspects of European monetary unification", NBER Working Paper no. 3949.

Begg I. ,2003, “Complementing EMU: Rethinking Cohesion Policy”, Oxford Review of Economic Policy, Vol. 19, No. 1, pp. 161-79.

Blanchard O. and Giavazzi F., 2002, "Current Account deficits in the Euro Area. The End of the Feldstein-Horioka Puzzle?", MIT Working Paper Series, no. 03-05.

Blanchard O., 2006, "Current Account Deficits in Rich Countries", IMF Mundell-Fleming Lecture.

Cappelen A., Castellacci F., Fagerberg J. and Verspagen B., 2003, “The Impact of EU Regional Support on Growth and Convergence in the European Union", Journal of Common Market Studies, Volume 41, No.4, pp 621644.

Christodoulakis N., Dimeli S. and Kollintzas T., 1995, "Business cycles in the EC: Idiosyncrasies and regularities", Economica, Vol. 62, No. 245, pp 127.

Christodoulakis N. and Kalyvitis S., 2002, "Growth, employment and the environment", Kluwer Academic publishers.

EC, 2005, "Working together for growth and jobs. A new start for the Lisbon strategy", Communication from the President, COM(2005), 24.

Duval R. and Elmeskov J., 2006, "The effects of EMU on structural reforms in labour and product markets", ECB Working Paper No. 596.

Dyson K., 2002, "EMU as Europeanization: Convergence, Diversity and Contingency", Journal of Common Market Studies, Vol.38, No.4, pp $645-666$ 
European Economy, 2008, “EMU@10: Successes and challenges after 10 years of Economic and Monetary Union", EC DG for Economic and Financial Affairs.

European Parliament, 1998, "Adjustment to Asymmetric Shocks", Working Paper, Economic Affairs Series, ECON 104.

Filippaios F. and Papanastassiou M. 2008, "US Outward Foreign Direct Investment in the European Union and the Implementation of the Single Market: Empirical evidence from a Cohesive Framework", Journal of Common Market Studies, Vol. 46, 5, 969-1000.

Frankel J. and Rose A., 1996, "The endogeneity of the Optimum Currency criteria", NBER Working Paper, no. 5700.

Gardiner B., Martin R. and Tyler P., 2004, "Competitiveness, Productivity and Economic Growth across the European Regions", Discussion Paper, University of Cambridge.

Giannone D. and Reichlin L., 2006, "Trends and cycles in the euro area: how much heterogeneity and should we worry about it? “, ECB Working Paper No. 595.

Gros D., 2006, "Italy and Germany: Convergence or divergence for the euro laggards?", CEPS Discussion Paper.

Gruber J. W. and Kamin S., 2008, "Do Differences in Financial Development Explain the Global Pattern of Current Account Imbalances?", Federal Reserve System, International Finance Discussion Papers, No. 923.

Hodrick R. J. and Prescott E. C., 1980, "Post-war US business cycles: an empirical investigation", Carnegie-Mellon University.

Kalemli-Ozcan S., Sorensen B. E and Yosha O., 2004, "Asymmetric Shocks and Risk Sharing in a Monetary Union: Updated Evidence and Policy Implications for Europe", CEPR Discussion Papers No. 4463.

Kok W., 2004, 'Facing the challenge: The Lisbon strategy for growth and Employment', Report from the High Level Group, European Commission, November.

Martin R., 2001, "EMU versus the regions? Regional convergence and divergence in Euroland," Journal of Economic Geography, vol. 1, No.1, pp 51-80.

Mundell, Robert, 1961, “A Theory of Optimum Currency Areas”, American Economic Review, Vol. 51, pp 509-517.

Rybsczynski, T., 1955, "Factor Endowments and Relative Commodity Prices", Economica, pp. 336-41.

Schiavo S., 2007, "Financial integration, GDP correlation and the Endogeneity of Optimum Currency Areas", Economica, 75, 297, pp 168-189. 
Shelburne R. C., 2008, "Current Account Deficits in European Emerging markets", UN Discussion Paper No. 2008.2

Schelkle W., 2007, "EMU: What did we think we know, what do we know and what should we know?", Working Paper, European Institute, LSE.

Sierminska E. and Takhtamanova Y., 2007, "Wealth Effect out of Financial and Housing Wealth: Cross-Country and Age Group Comparisons", FRB San Francisco Paper.

Tenreyo S. and Barro R., 2003, "Economic Effects of Currency Unions", NBER WP No. 9435.

Turnovsky S. 1996, "Endogenous Growth in a Dependent Economy with Traded and Non-Traded Capital", Review of International Economics, Vol. 4, No.3, pp 300-321.

Weber A., 1990, "Asymmetries and adjustment problems: some empirical evidence", European Economy.

Wincoop van E., 1990, "Structural adjustment and the construction sector", European Economic Review, 37, pp 177-201. 


\section{Appendix A: Data sources}

Eurozone countries: The twelve countries that participated in the Eurozone from the first round are considered here (AT, BE, EL, FI, FR, GE, IE, IT, LX, NE, PT and SP). Although Greece (EL) was authorized to join the Eurozone in 2000 and became a member in 1/1/2001, it is treated the same as the other countries that participated in 1/1/1999. Luxembourg is left out from most of the Eurozone indicators constructed for the present study, because its huge financial transactions relative to its population would jeopardize any meaningful comparisons with the other member-states.

Per capita GDP, GNI, and GDP in PPS: Eurostat, Data series, 2008; in constant Euros 2000.

Per capita regional income: Eurostat, regional indicators, containing 144 NUTS-2 regions of the 12 first-round Eurozone countries.

Current Account, Trade balance: Eurostat, Data series, 2008; as ratios to GDP.

Capital Formation: Eurostat, Data series, 2008; as percent of GDP.

Public Investment: Eurostat, Data series, 2008; as percent of GDP.

Foreign Direct Investment, Stock and Flows: UNCTAD, Beyond 20/20 WDS, Major FDI indicators (WIR 2008).

Factor Income from Abroad: OECD, Annual Data.

House rental prices: Eurostat, annual average index (cp041, avx) 


\section{Appendix B: Unit-root tests}

Unit-root tests are performed for the growth rates for one and four periods as in the 1.h.s. in equations (4a) and (4b) respectively and for the level gaps between a country's per capita GDP and the group mean. Both the null hypotheses of a common unit-root or individual unit-roots are tested over the period 1990-2007, without using individual intercepts in the estimations. Results show a clear rejection of the null hypotheses for all cases at the 5\% level and below.

Table 3 : Unit-root test for the pooled series of growth rates and level gaps.

\begin{tabular}{|c|c|c|c|c|c|c|}
\hline Series & $g=y / y(-1$ & & $g=y /(y(-4$ & & y/y_meal & \\
\hline & statistic & Prob & statistic & Prob & statistic & Prob \\
\hline $\begin{array}{l}\text { Common process } \\
\text { Levine, Lin \& Chu-t }\end{array}$ & -5.36 & 0.00 & -3.89143 & 0.00 & -4.68814 & 0.00 \\
\hline $\begin{array}{l}\text { Individual } \\
\text { processes } \\
\text { Augmented } \\
\text { Dickey-Fuller }\end{array}$ & 59.30 & 0.00 & 41.2677 & 0.00 & 48.3484 & 0.00 \\
\hline Phillips-Perron & 56.85 & 0.00 & 35.00 & 0.0387 & 55.0734 & 0.0001 \\
\hline
\end{tabular}

Figure 1a. Per capita GDP fluctuations in the twelve Eurozone countries (expressed as \% of the trend in each country's GDP per capita in constant terms)

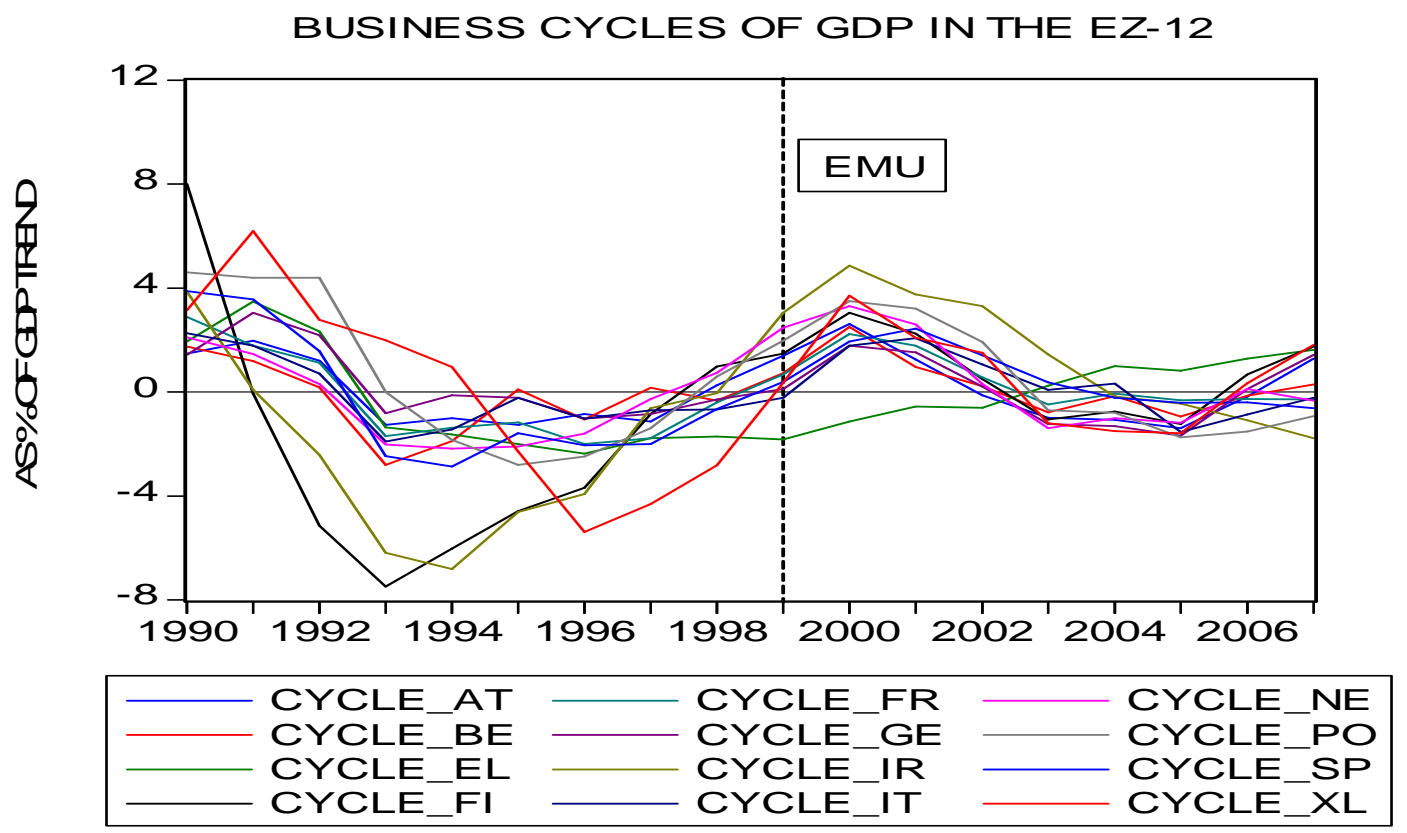


Figure 1b. Dispersion of per capita GDP fluctuations in the twelve Eurozone countries (Standard deviation of cycles as \% of the trend mean).

DIVERGENGE OF GDP FLUCTUATIONS IN EZ-12

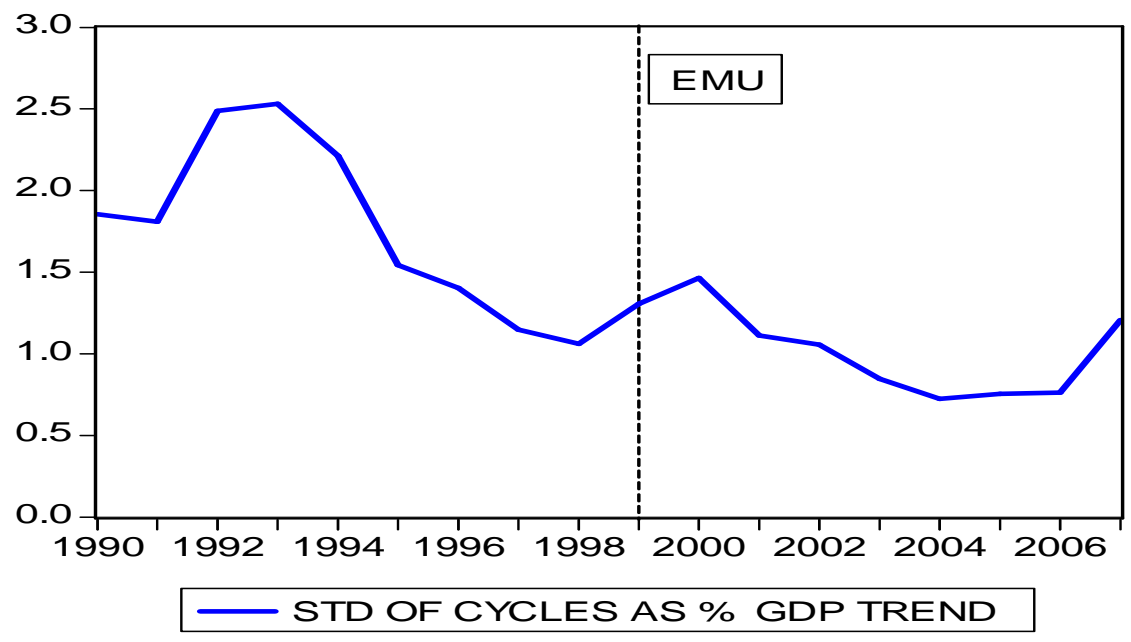

Figure 1c. Variances of GDP per capita in constant prices before \& after EMU.

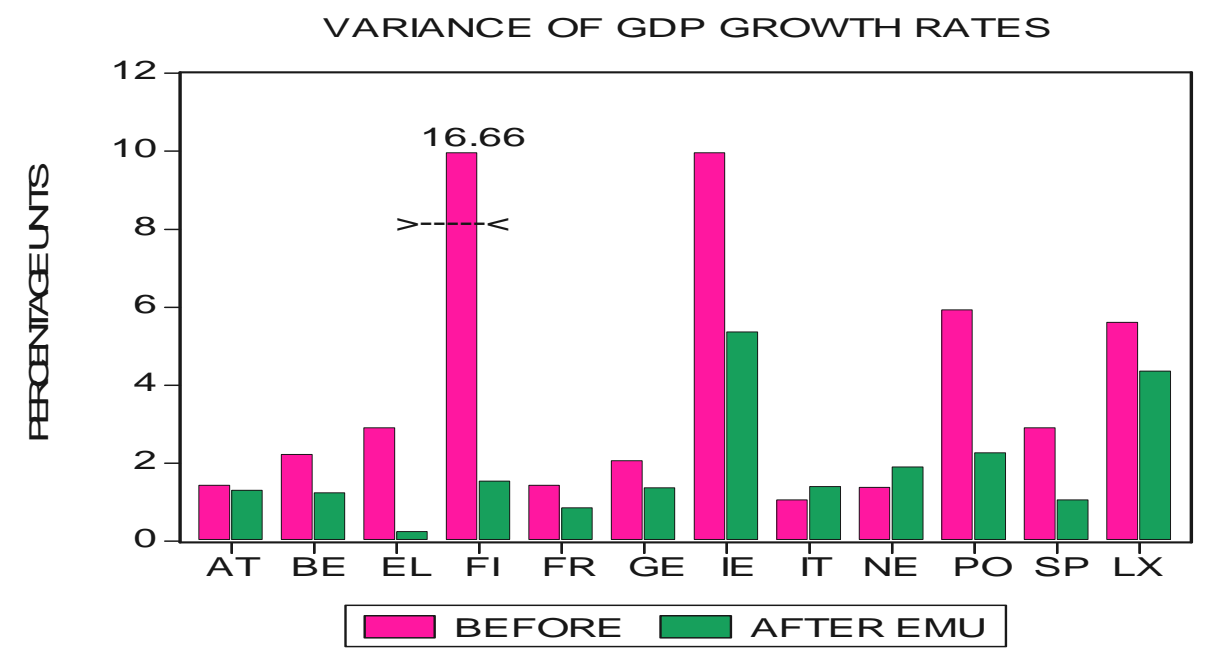

Figure 2a. Dispersion of per capita GDP expressed in PPS terms.

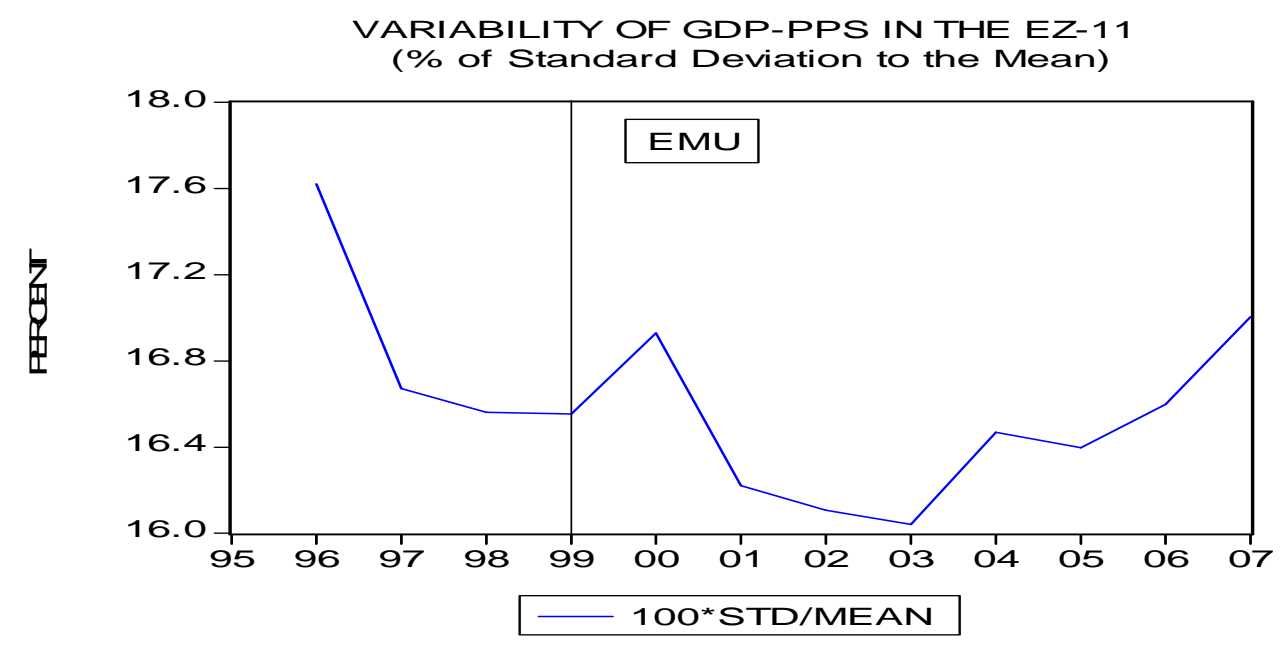


Figure 2b. Dispersion of per capita regional income (Standard deviation as \% of the regional income mean).

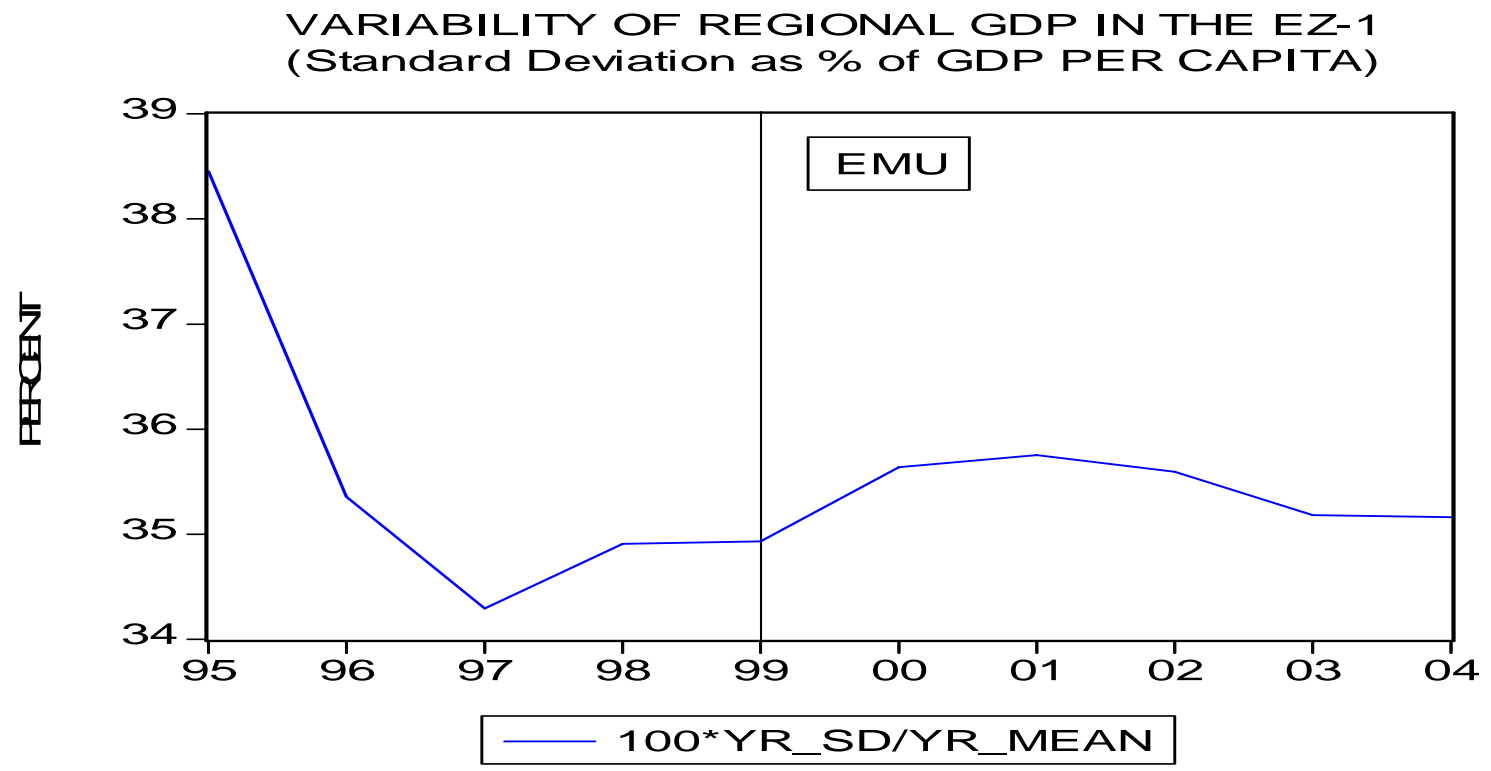

Figure 2c. Dispersion of per capita GDP and GNI in constant prices

(Standard deviation as \% of the mean).

VARIABILITY OF GDP AND GNI IN EZ11

(In per capita constant prices. Source: Eurostat)

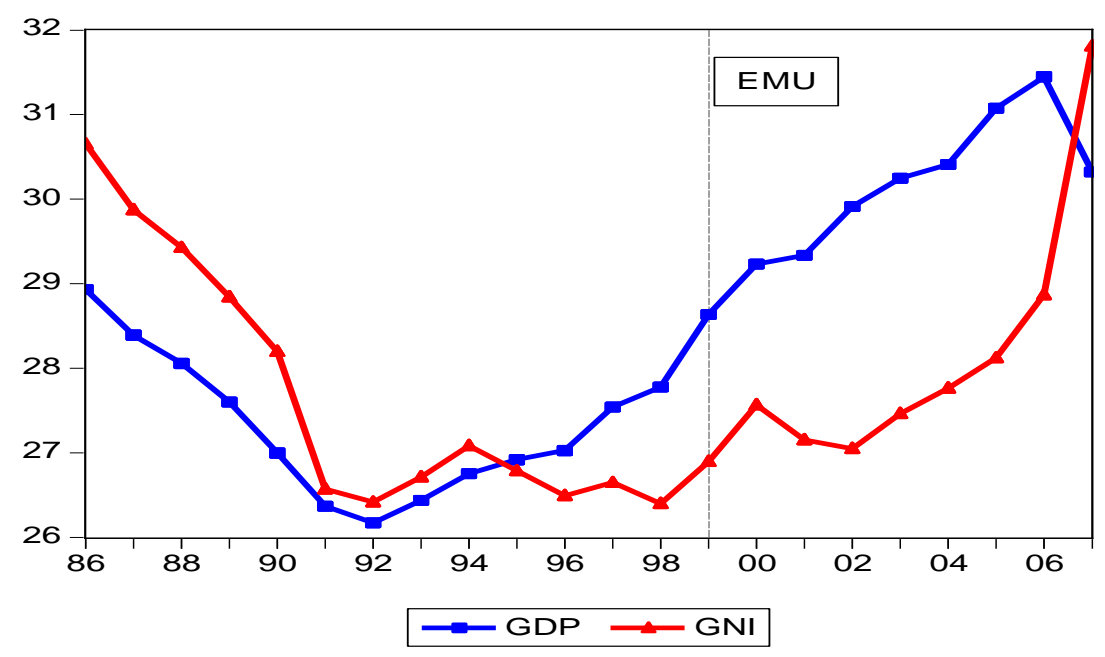


Figure 3a. Pre-EMU correlation of growth rates with initial per capita incomes.

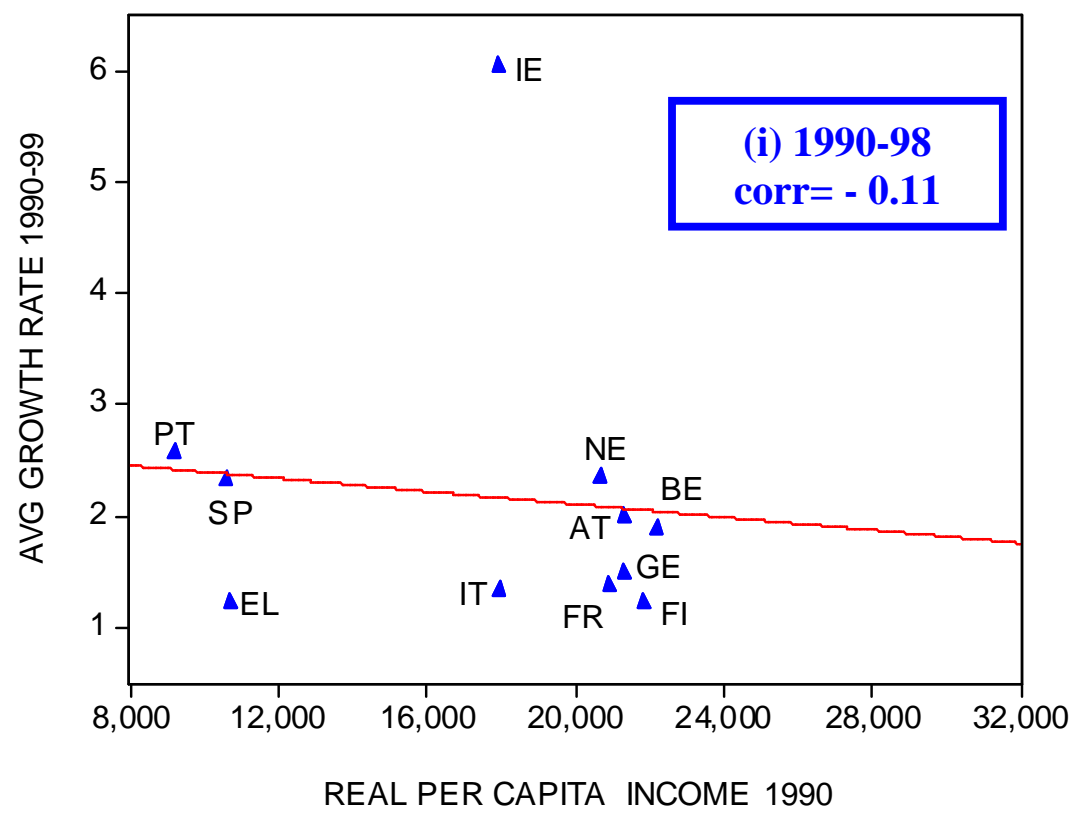

Figure 3b. Post-EMU correlation of growth rates with initial per capita incomes

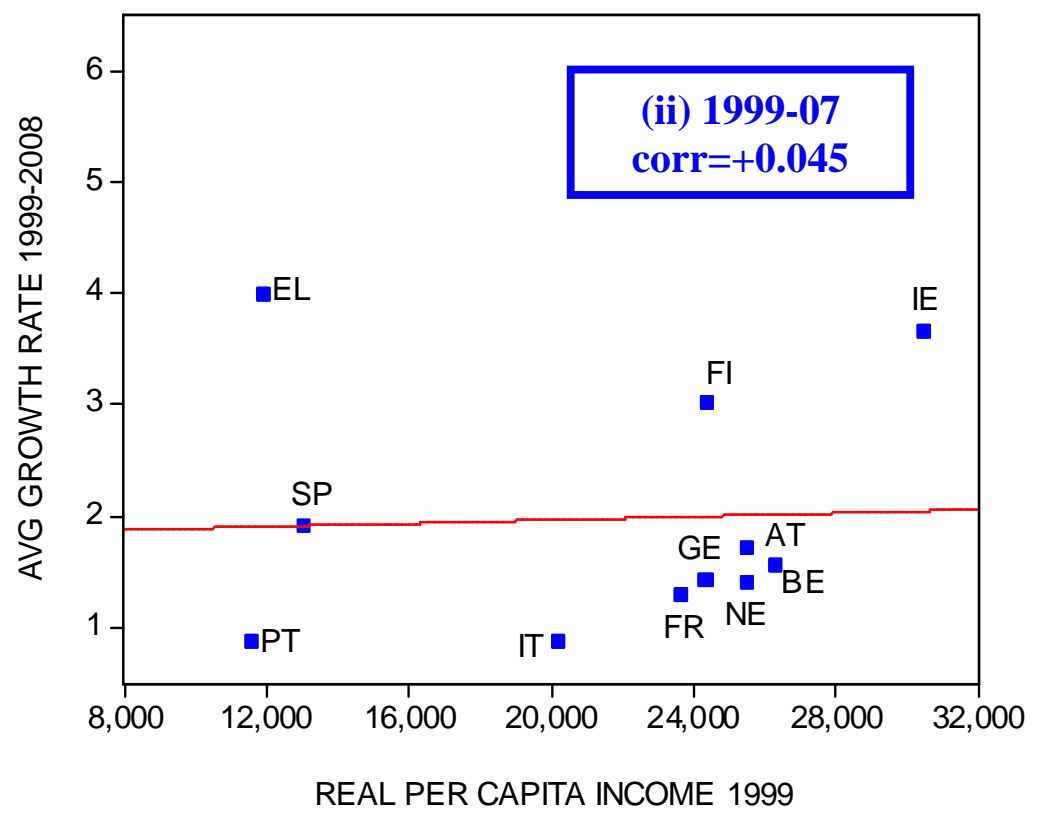


Figure 4a. Current Accounts and Trade Balances as \% of GDP in the two Eurozone groups.

CURRENT ACCOUNTS \& TRADE BALANCES

AS PERCENT OF GDP (Source: Eurostat)

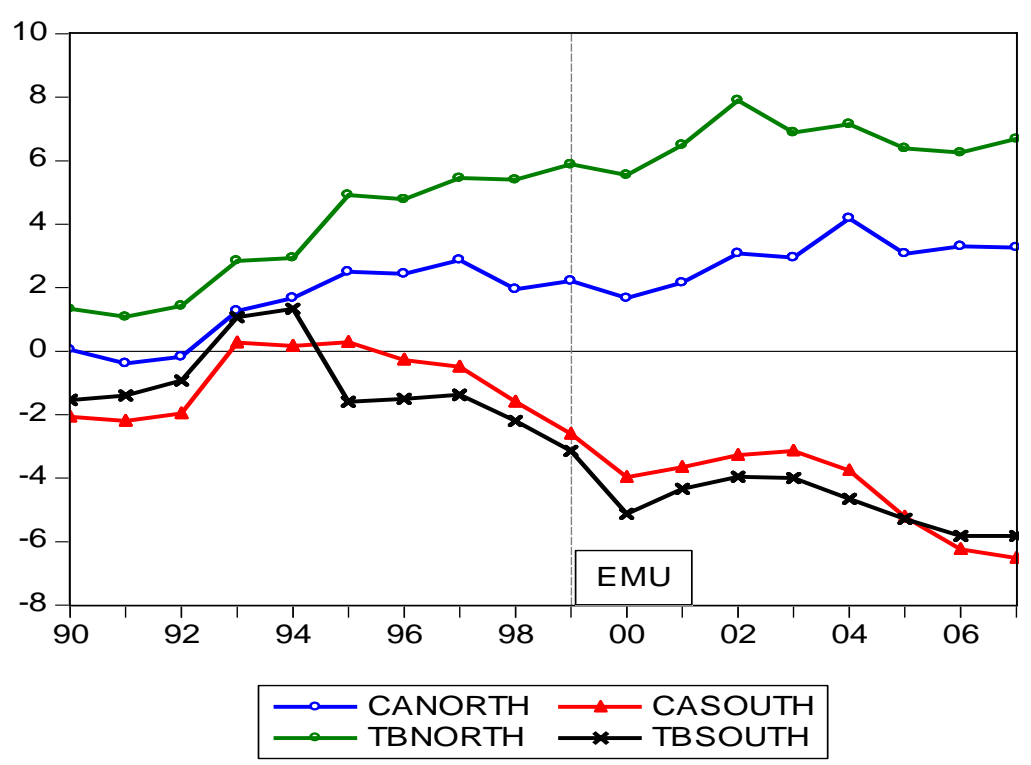

Figure $4 \mathrm{~b}$. The ratio of $\mathrm{CA}$ deficits to capital formation for the five southern Eurozone economies

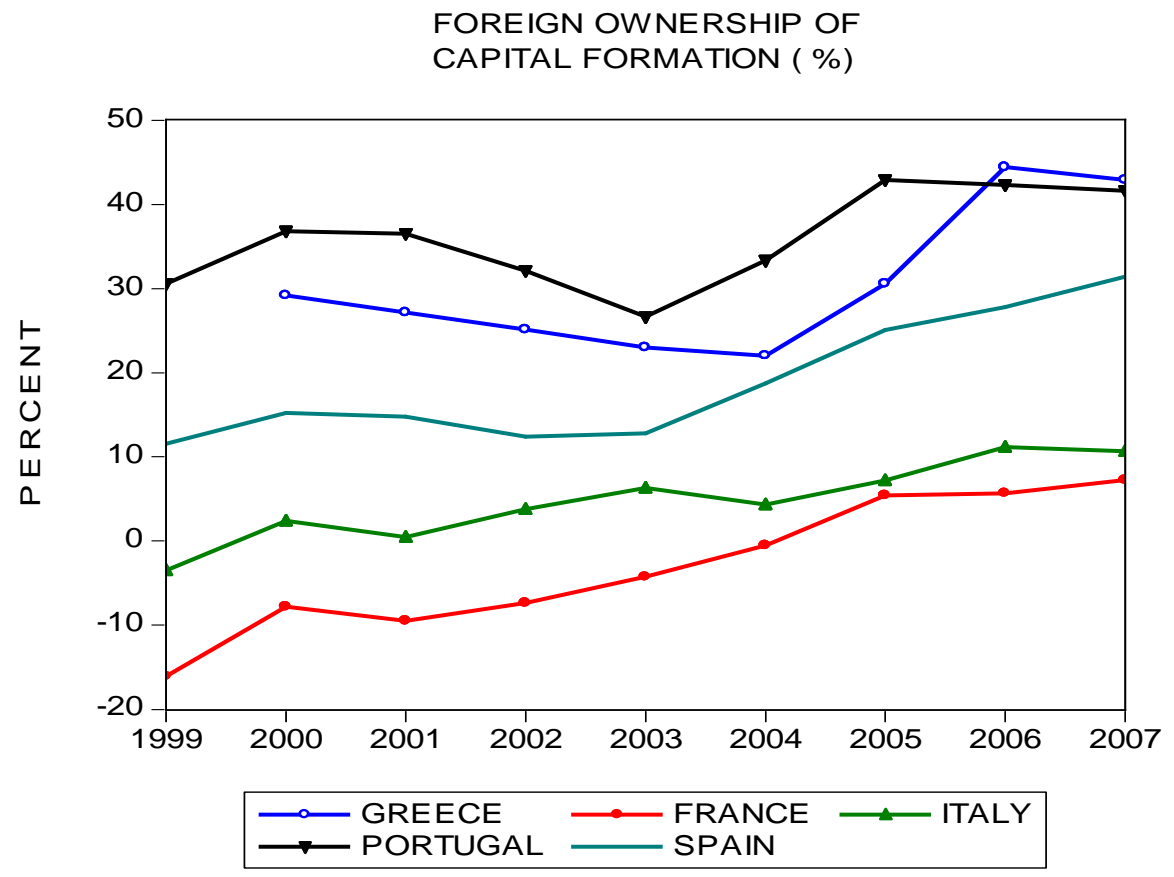


Figure 5a: Correlation between CA Balances and Government Balances in the southern Eurozone countries before EMU.

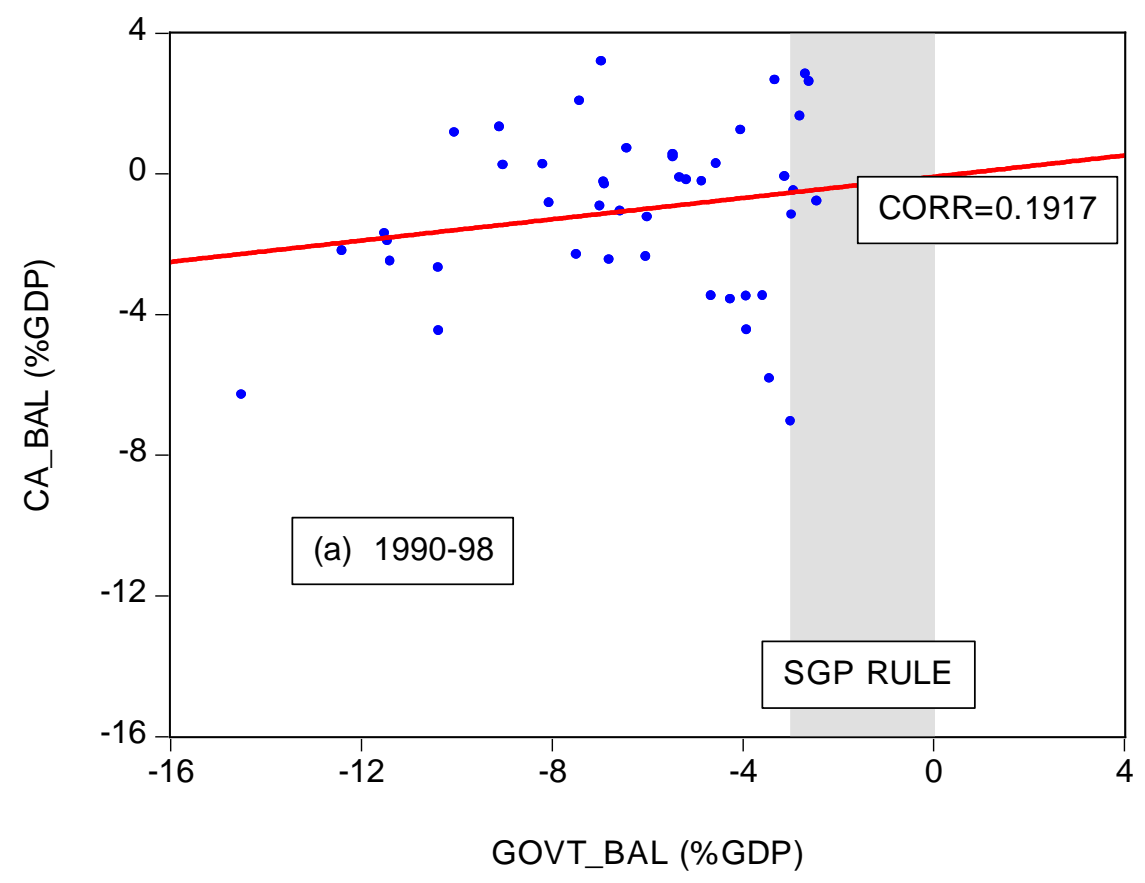

Figure 5b: Correlation between CA Balances and Government Balances in the southern Eurozone countries after EMU.

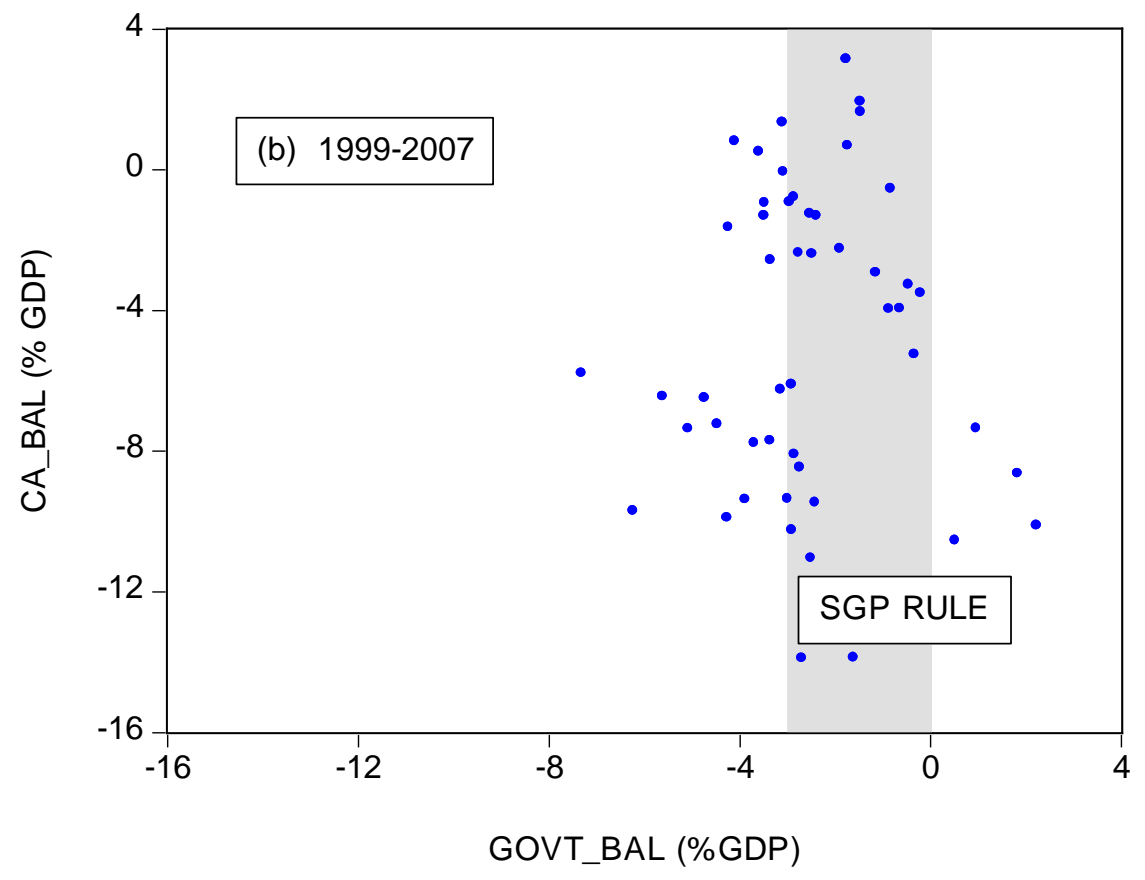


Figure 6a: Correlations between Trade Balances and Inward Investment in the northern Euro-area countries 1990-2006.
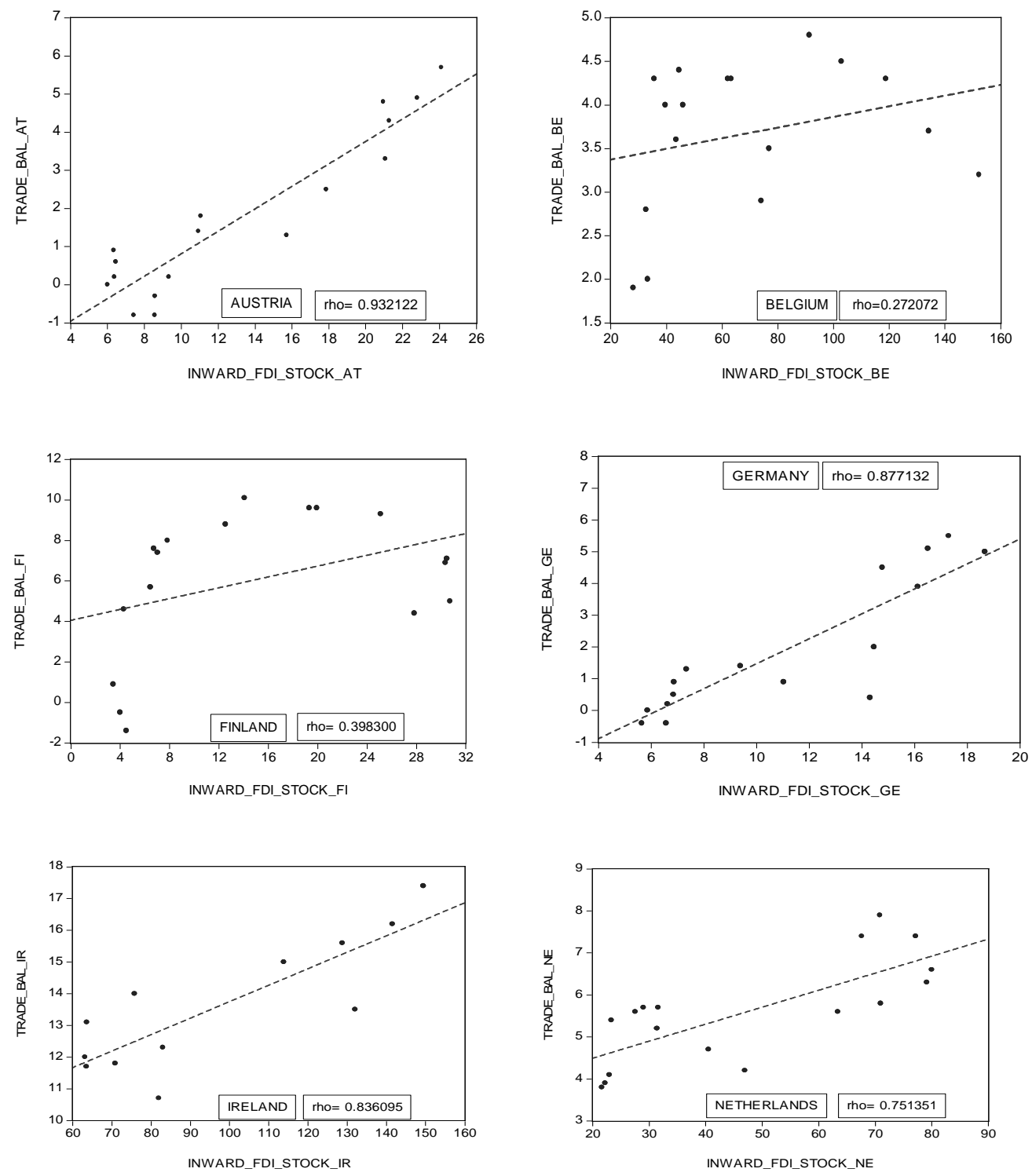
Figure 6b: Correlation between Trade Balances and Inward Investment in the southern Euro-area countries 1990-2006.
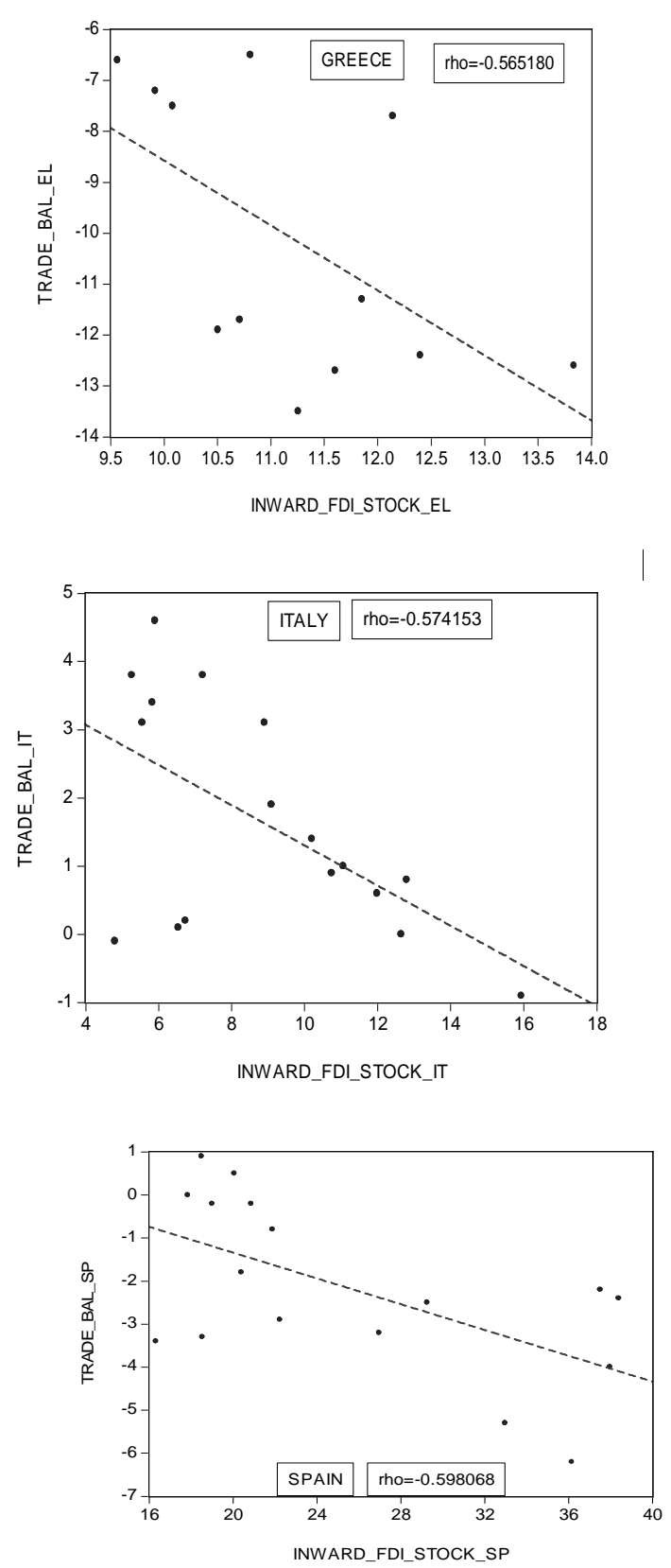
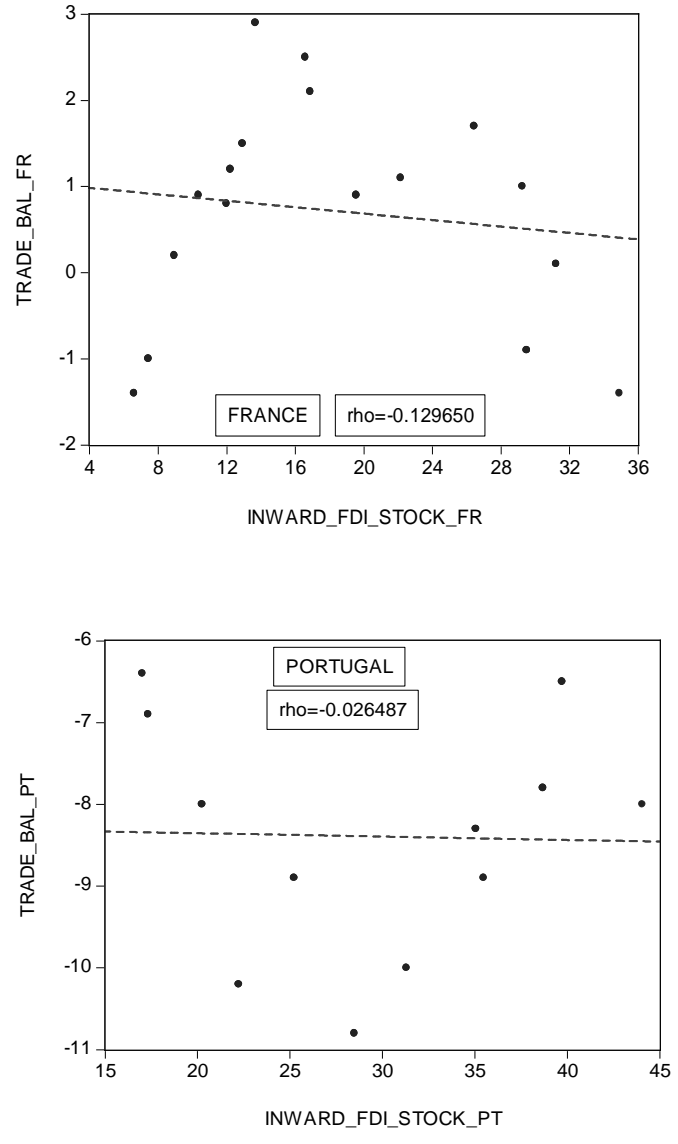
Figure 7. Index of house rental prices in the two groups of Eurozone.

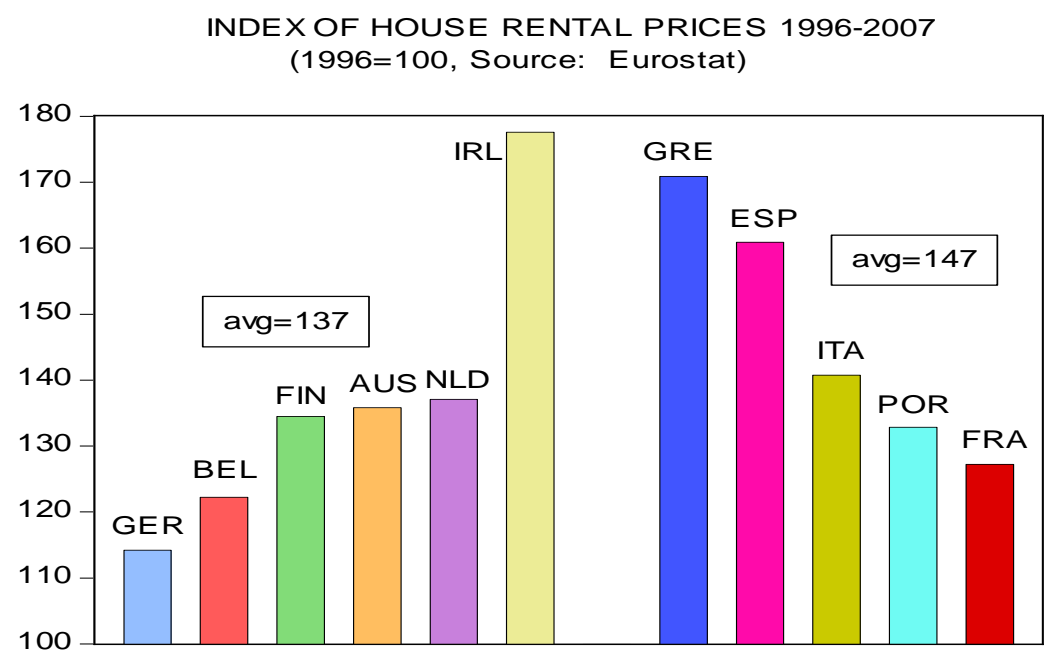

Note: The average index for the two groups is shown in boxes. Excluding Ireland, the index falls to $128,14 \%$ lower than that of the south.

Figure 8. Net FDI flows (inward - outward investment) in the two groups of Eurozone.

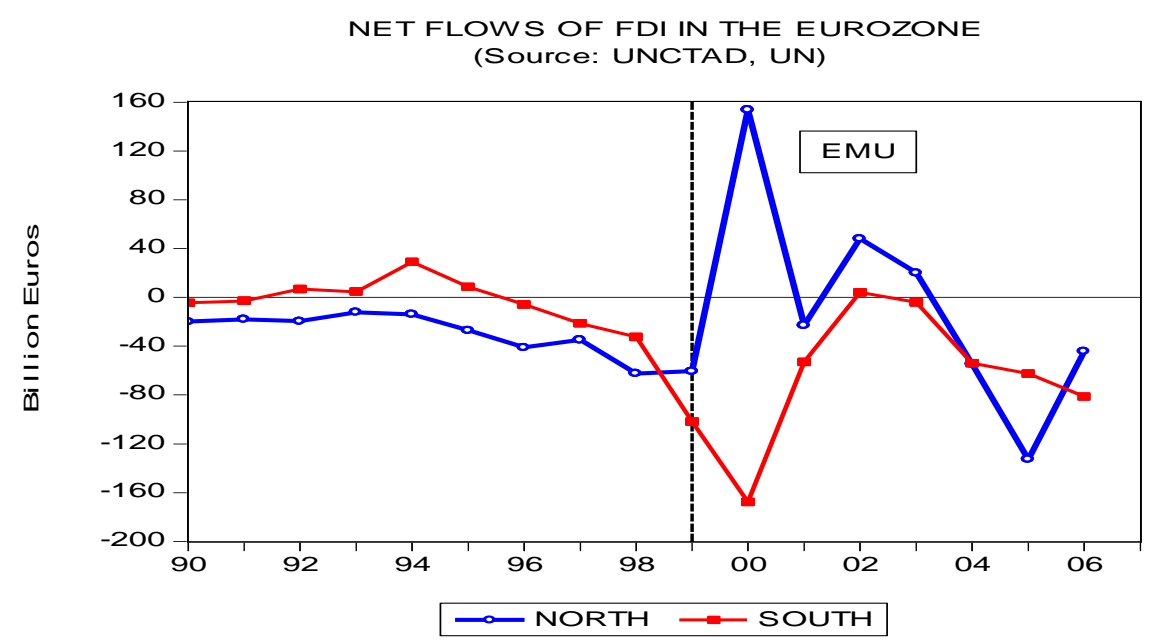





\section{Other papers in this series}

Christodoulakis, Nikos, Ten Years of EMU: convergence, divergence and new policy priorities, GreeSE Paper No22, January 2009

Boussiakou Iris, Religious Freedom and Minority Rights in Greece: the case of the Muslim minority in western Thrace GreeSE Paper No21, December 2008

Antigone Lyberaki, "Deae ex Machina”: migrant women, care work and women's employment in Greece, GreeSE Paper No20, November 2008

Ker-Lindsay, James, The security dimensions of a Cyprus solution, GreeSE Paper No19, October 2008

Economides, Spyros, The politics of differentiated integration: the case of the Balkans, GreeSE Paper No18, September 2008

Fokas, Effie, A new role for the church? Reassessing the place of religion in the Greek public sphere, GreeSE Paper No17, August 2008

Klapper, Leora and Tzioumis, Konstantinos, Taxation and Capital Structure: evidence from a transition economy, GreeSE Paper No16, July 2008

Monastiriotis, Vassilis, The Emergence of Regional Policy in Bulgaria: regional problems, EU influences and domestic constraints, GreeSE Paper No15, June 2008

Psycharis, Yannis, Public Spending Patterns:The Regional Allocation of Public Investment in Greece by Political Period, GreeSE Paper No14, May 2008

Tsakalotos, Euclid, Modernization and Centre-Left Dilemmas in Greece: the Revenge of the Underdogs, GreeSE Paper No13, April 2008

Blavoukos, Spyros and Pagoulatos, George, Fiscal Adjustment in Southern Europe: the Limits of EMU Conditionality, GreeSE Paper No12, March 2008

Featherstone, Kevin, 'Varieties of Capitalism' and the Greek case: explaining the constraints on domestic reform?. GreeSE Paper No11, February 2008 
Monastiriotis, Vassilis, Quo Vadis Southeast Europe? EU Accession, Regional Cooperation and the need for a Balkan Development Strategy, GreeSE Paper No10, January 2008

Paraskevopoulos, Christos, Social Capital and Public Policy in Greece. GreeSE Paper No9, December 2007

Anastassopoulos George, Filippaios Fragkiskos and Phillips Paul, An 'eclectic' investigation of tourism multinationals' activities: Evidence from the Hotels and Hospitality Sector in Greece, GreeSE Paper No8, November 2007

Watson, Max, Growing Together? - Prospects for Economic Convergence and Reunification in Cyprus, GreeSE Paper No7, October 2007

Stavridis, Stelios, Anti-Americanism in Greece: reactions to the 11-S, Afghanistan and Iraq, GreeSE Paper No6, September 2007

Monastiriotis, Vassilis, Patterns of spatial association and their persistence across socio-economic indicators: the case of the Greek regions, GreeSE Paper No5, August 2007

Papaspyrou, Theodoros, Economic Policy in EMU: Community Framework, National Strategies and Greece, GreeSE Paper No4, July 2007

Zahariadis, Nikolaos, Subsidising Europe's Industry: is Greece the exception?, GreeSE Paper No3, June 2007

Dimitrakopoulos, Dionyssis, Institutions and the Implementation of EU Public Policy in Greece: the case of public procurement, GreeSE Paper No2, May 2007

Monastiriotis, Vassilis and Tsamis, Achilleas, Greece's new Balkan Economic Relations: policy shifts but no structural change, GreeSE Paper No1, April 2007

\section{Other papers from the Hellenic Observatory}

Papers from past series published by the Hellenic Observatory are available at http://www.lse.ac.uk/collections/hellenicObservatory/pubs/DP_oldseries.htm 